\title{
Trace-element abundances in the shallow lithospheric mantle of the North Atlantic Craton margin: Implications for melting and metasomatism beneath Northern Scotland
}

\author{
Hannah S. R. Hughes ${ }^{1, *, \dagger}{ }^{\text {, Iain McDonald }}{ }^{1}$, John W. Faithfull ${ }^{2}$, Brian G. J. Upton ${ }^{3}$ and Hilary Downes ${ }^{4}$ \\ 1 School of Earth and Ocean Sciences, Cardiff University, Main Building, Cardiff CF10 3AT, UK \\ 2 Hunterian Museum and Art Gallery, University of Glasgow, Glasgow G12 8QQ, UK \\ 3 School of Geosciences, University of Edinburgh, Edinburgh EH9 3JW, UK \\ 4 Department of Earth and Planetary Sciences, Birkbeck University of London, Malet Street, London WC1E 7HX, UK
}

[Received 30 October 2014; Accepted 2 February 2015; Associate Editor: R. Mitchell]

\section{ABSTRACT}

Bulk rock geochemistry and major- and trace-element compositions of clinopyroxene have been determined for three suites of peridotitic mantle xenoliths from the North Atlantic Craton (NAC) in northern Scotland, to establish the magmatic and metasomatic history of subcontinental lithospheric mantle (SCLM) below this region. Spinel lherzolites from the southernmost locality (Streap Com'laidh) have non-NAC mantle compositions, while the two northern xenolith suites (Loch Roag and Rinibar) are derived from the thinned NAC marginal keel. Clinopyroxene compositions have characteristic trace-element signatures which show both 'primary' and 'metasomatic' origins. We use $\mathrm{Zr}$ and $\mathrm{Hf}$ abundances to identify ancient cryptic refertilization in 'primary' clinopyroxenes. We suggest that Loch Roag and Rinibar peridotite xenoliths represent an ancient ArchaeanPalaeoproterozoic SCLM with original depleted cratonic signatures which were overprinted by metasomatism around the time of intrusion of the Scourie Dyke Swarm ( 2.4 Ga). This SCLM keel was preserved during Caledonian orogenesis, although some addition of material and/or metasomatism probably also occurred, as recorded by Rinibar xenoliths. Rinibar and Streap xenoliths were entrained in Permo-Carboniferous magmas and thus were isolated from the SCLM 200 Ma before Loch Roag xenoliths (in an Eocene dyke). Crucially, despite their geographical location, lithospheric mantle peridotite samples from Loch Roag show no evidence of recent melting or refertilization during the Palaeogene opening of the Atlantic.

Keywords: North Atlantic Craton, spinel lherzolite, xenolith, REE, clinopyroxene.

\section{Introduction}

MANTLE xenoliths provide a direct (if incomplete) view into the lithospheric mantle underlying the Earth's crust. Xenolith assemblages are the composite result of magmatic and/or metasomatic events and record transient volatiles and fluids.

\footnotetext{
* E-mail: hannah.hughes@wits.ac.za

$\dagger$ Present address: School of Geosciences, University of the Witwatersrand, Private Bag 3, Wits 2050, Johannesburg, South Africa

DOI: $10.1180 /$ minmag.2015.079.4.03
}

Interest in the SCLM and its role as a source or sink of metals such as $\mathrm{Cu}$, Mo and $\mathrm{Au}$, has been discussed in the literature for decades (c.f. Groves et al., 1987; Groves and Bierlein, 2007 and references therein). However, recent interest in how the SCLM relates to critical metals and 
metals of strategic and economic importance (such as the platinum-group elements (PGE) and rare-earth elements $(R E E)$ ) has re-ignited this debate (e.g. Arndt, 2013).

The composition of the ancient Archaean SCLM beneath the NAC has already been explored in various studies in Greenland (e.g. Bernstein et al., 1998; Hanghøj et al., 2001; Bizzarro and Stevenson, 2003; Bernstein et al., 2006; Wittig et al., 2008; 2010; Tappe et al., 2011; Bernstein et al., 2013). Xenolith suites from both West and East Greenland comprise a mix of depleted harzburgitic lithologies, eclogites, dunites and wehrlites, as well as more 'fertile' lherzolite peridotites. Typically NAC mantle xenoliths encompass both spinel and garnetbearing rocks, corroborating seismic tomographic evidence that these ancient lithospheric keels extend to depths $>100 \mathrm{~km}$ (Kumar et al., 2005). Research into the mineralogy and isotopic composition of mantle xenoliths from the eastern fragment of the NAC margin in northwest Scotland (UK) has resulted in the identification of several suites of spinel-lherzolite xenoliths (see Upton et al., 2011 and references therein). These localities are all situated north of the Great Glen Fault, and are hosted in Permo-Carboniferous and Eocene basic dykes (Upton et al., 2011).

In this study, we present whole-rock major- and trace-element geochemistry for a selection of northwest Scottish spinel lherzolite mantle xenoliths. Samples were chosen to represent the freshest lithospheric mantle material in this region, and therefore provide an excellent opportunity to study the composition of the mantle of the cratonic margin of the NAC. We compare these xenoliths to suites from the centre of the NAC in Greenland, and investigate their whole-rock compositions, silicate mineral traceelement chemistry (specifically clinopyroxene) and accessory mineralogy to identify various metasomatic signatures and constrain the evolution of this part of the NAC.

\section{Overview of the North Atlantic Craton -} formation, amalgamation and xenolith localities

The North Atlantic Craton (NAC) extends from eastern Canada (Nain Province), through Greenland, and includes a fragment in the United Kingdom known locally as the Lewisian Gneiss Complex (Fig. 1). The NAC consists of amalgamated Archaean domains with zones of Palaeoproterozoic reworking (e.g. Bridgwater et al., 1973). The geological history of the Lewisian fragment can be subdivided according to the following major tectonic events (see Park, 2005 and references therein): (1) magmatic protolith formation (including ultramafic-mafic bodies now preserved as pods within tonalite-trondhjemitegranodiorite (TTG) gneisses) at $3.0-2.8 \mathrm{Ga}$; (2) high-grade regional metamorphism followed by the initiation of shear zones and associated metamorphism at 2.8-2.5 Ga. Undeformed granitoids from parts of the Lewisian date from $2.8-2.7 \mathrm{Ga}$ and could be coincident with the alkaline province of Skjoldungen in east Greenland (Goodenough et al., 2014 and references therein). This was associated with extensive partial melting (known as the 'Badcallian' event) however the precise date of this melting event is difficult to constrain (Goodenough et al., 2014). Orogenic events elsewhere in the Greenlandic portion of the NAC at $\sim 2.86-2.60 \mathrm{Ga}$ are associated with gold mineralization (e.g. Kolb et al., 2013). (3) Intrusion of mafic-ultramafic dykes (Scourie Dykes) 2.4-2.3 Ga during a period of continental rifting and extension (Davies and Heaman, 2014); (4) 2.0-1.8 Ga calc-alkaline magmatism and volcanic arc accretion, with the

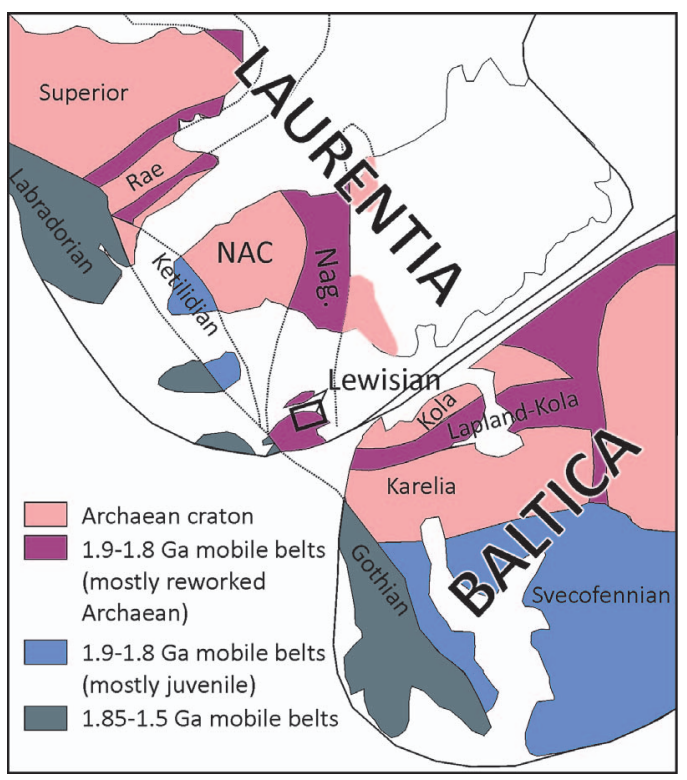

Fig. 1. Palaeoproterozoic reconstruction of the North Atlantic Craton (NAC), reworked NAC mobile belts and other 'juvenile' mobile belts. Based on Buchan et al. (2000). The Scottish portion of the NAC is labelled 'Lewisian'. 
formation of Laxfordian high-grade metamorphic belts; (5) continued calc-alkaline magmatism $\sim 1.8-1.7 \mathrm{Ga}$, including further deformation and prograde amphibolite-facies metamorphism and Laxfordian crustal anatexsis (Bridgwater et al., 1973; Park, 1994; Park, 1995; Kinny et al., 2005; Park, 2005; Hughes et al., 2014; Vernon et al., 2014).

The western part of the NAC in Greenland hosts abundant late Proterozoic ultramafic lamprophyre dykes and sills and kimberlites, which contain mantle xenoliths (c.f., Bizzarro and Stevenson, 2003; Tappe et al., 2006; Bernstein et al., 2007; Tappe et al., 2007; Wittig et al., 2010 and references therein). Xenolith/xenocryst suites comprise (variably) serpentinized ultra-refractory dunites, harzburgites, eclogites, wehrlites and minor lherzolites (e.g. Hutchison and Frei, 2009). The mantle lithologies have unradiogenic Os-isotope compositions (mean $\gamma \mathrm{Os}=-9.2$ ) and Re-depletion model eruption ages $\left(T_{\mathrm{RD}}{ }^{\text {erupt }}\right)$ of 3.2 to $2.7 \mathrm{Ga}$ and $2.0 \mathrm{Ga}$ (Wittig et al., 2010). In the southwest portion of the NAC, xenoliths entrained in Mesozoic kimberlites have undergone comparatively little serpentinization. Whilst the silicate mineralogy and whole-rock major-element composition of these xenoliths record severe depletion, they have more radiogenic Os-isotope compositions (mean $\gamma \mathrm{Os}=-7.2$ ) and a single $T_{\mathrm{RD}}^{\text {erupt }}$ at $2.0 \mathrm{Ga}$ (Wittig et al., 2010). Overall, thermobarometric studies of western Greenlandic NAC xenoliths suggest that most were derived from 180-220 km depth (Bizzarro and Stevenson, 2003; Sand et al., 2009). Studies by Bizzarro and Stevenson (2003) indicate that the western Greenlandic NAC may be stratified, consisting of two major 'units': an upper zone of more refractory peridotites $(70-180 \mathrm{~km}$ depth), and a lower 'fertile' clinopyroxenebearing lherzolite zone $(180-225 \mathrm{~km})$.

Palaeogene dykes at the eastern Greenlandic margin of the NAC, at Wiedemann Fjord, have also yielded xenoliths of depleted peridotites, predominantly spinel harzburgites (Bernstein et al., 1998; Hanghøj et al., 2001 and references therein). East Greenlandic xenoliths preserve highly refractory and severe melt depletion signatures (including highly forsteritic olivine and low modal orthopyroxene) and are thought to record formation of the North Atlantic cratonic mantle keel with further Palaeogene partial melting and depletion during the opening of the Atlantic (Bernstein et al., 1998). The same xenolith suite however also contains a spectrum of peridotite compositions which include lherzolites with variable olivine content (down to 50\%) and up to 25\% clinopyroxene (Hanghøj et al., 2001). As with the western Greenlandic NAC, Os-isotopic compositions from these eastern Greenlandic NAC xenoliths record Archaean polybaric melt depletion for the harzburgites, initiating at $\geqslant 7 \mathrm{GPa}$ $(\sim 210 \mathrm{~km})$ and continuing at $2-3 \mathrm{GPa}$ $(65-100 \mathrm{~km})$ (Bernstein et al., 1998). Later refertilization of restites added pyroxene (particularly clinopyroxene) and re-equilibrated the modal mineral and isotopic compositions at high temperatures (up to $980^{\circ} \mathrm{C}$ ). This may have taken place during Palaeogene magmatism associated with the opening of the Atlantic and impingement of the Icelandic mantle plume (e.g. Hanghøj et al., 2001). Hence, both depletion and refertilization are thought to be recorded in the keel of the NAC SCLM in the eastern Greenlandic, following Palaeogene mantle-plume magmatism.

\section{The Scottish portion of the North Atlantic Craton and neighbouring terranes}

In Scotland, mantle xenolith localities occur within five tectonic terranes, delineated by major crustal (and probably lithospheric) lineaments (Fig. 2). In the far northwest of Scotland, the Archaean-Mesoproterozoic Lewisian Gneiss complex makes up much of the British portion of the NAC, and is the exposed basement of the Caledonian foreland bounded to the east by the Moine Thrust Zone (MTZ). Adjacent to this, and bounded to the southeast by the Great Glen Fault, is the Northern Highland terrane which at surface comprises predominantly $\sim 1$ Ga Moinian metasediments, intercalated with 'Lewisianoid' inliers (Tanner, 1970) which suggest that Archaean basement (at least at the crustal level) extends east beyond the MTZ and underlies the Northern Highland terrane (e.g. Moorhouse and Moorhouse, 1977). Ordovician-Silurian high $\mathrm{Ba}-\mathrm{Sr}$ mixed diorite-granitoid, syenite and pyroxenite-syenite alkaline intrusions occur across the Northern Highland terrane and includes the only carbonatite intrusion in the UK (Loch Urigill; Young et al., 1994). Further, a peralkaline granite intrusion occurred in the late Proterozoic (Carn Cuinneag granite at $594 \mathrm{Ma}$; Oliver et al., 2008) and could attest to a lithospheric mantle magmatic event at this time.

The subduction of Iapetus oceanic lithosphere below Avalonia was initiated during the Grampian 


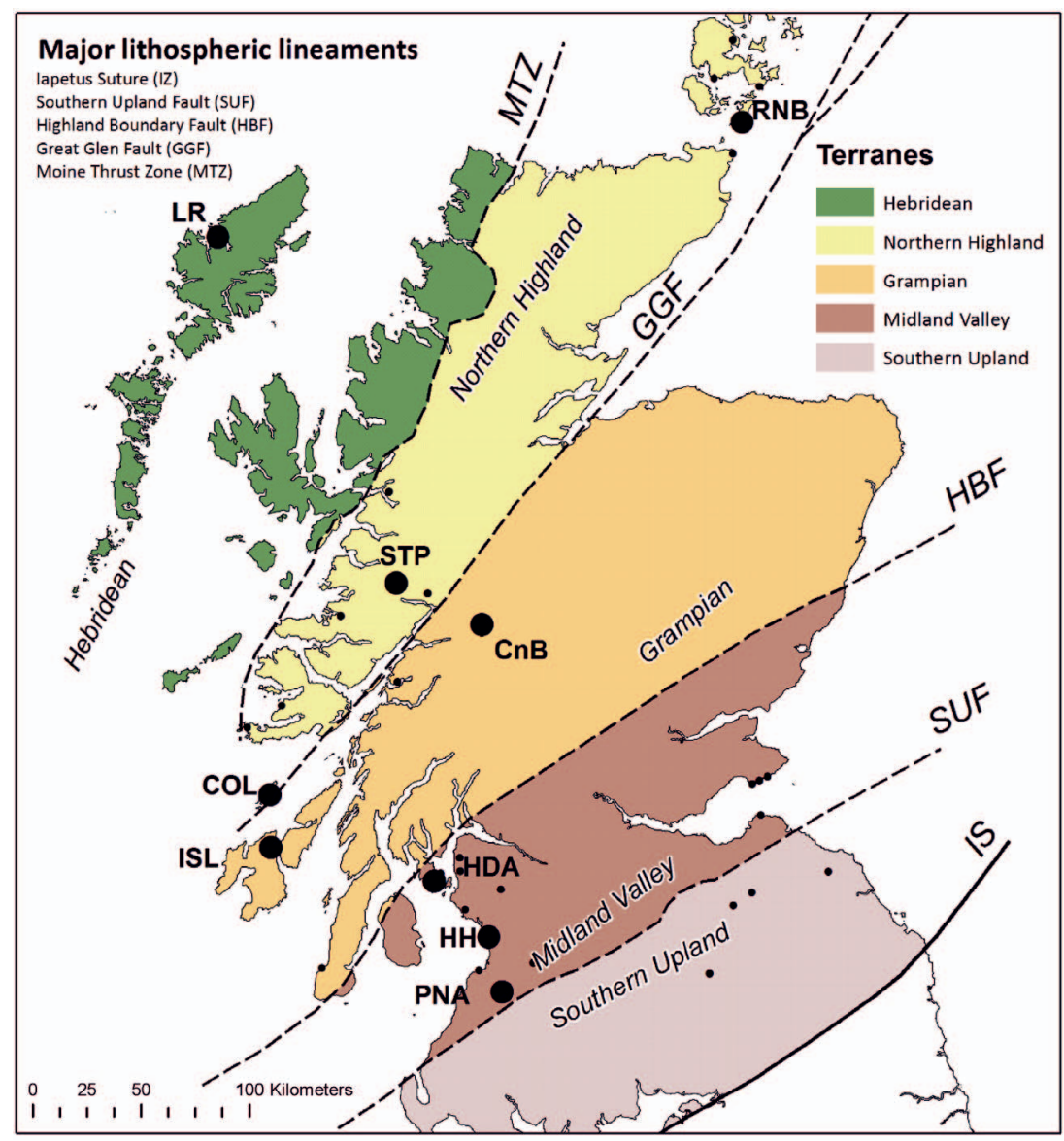

FIG. 2. Terrane map of Scotland, highlighting major mantle xenolith localities. The three suites north and northwest of the Great Glen Fault (GGF) are included in this study; Loch Roag (LR), Streap Com'laidh (STP) and Rinibar (RNB). These span two terranes - the Hebridean Terrane and Northern Highland terrane - both of which are thought to be underlain by (re-worked) NAC basement. Other xenolith localities labelled are: Colonsay (COL), Islay

(ISL), Coire na Ba (CnB), Heads of Ayr (HDA), Hillhouse (HH) and Patna (PNA).

Event (478-460 Ma) and resulted in the tectonic stacking and metamorphism of Dalradian strata and deformation of the Southern Uplands (Stone et al., 1987; Kinny et al., 2003). The Iapetus subduction ended $\sim 450 \mathrm{Ma}$ (Neilson et al., 2009) and by $\sim 430 \mathrm{Ma}$ continent-continent collision had commenced with the edge of Avalonia emplaced beneath that of Laurentia (Stone et al., 1987; Kneller, 1991). The Moine Thrust Zone (MTZ; Fig. 2) was formed by large-scale horizontal shortening of the crust in the early Silurian. Movement along the MTZ largely ceased at $\sim 429 \mathrm{Ma}$ (Goodenough et al., 2011). The Great Glen Fault (GGF; Fig. 2) forms the most important terrane boundary and lineament in Scotland. Fundamentally, the GGF separates northern terranes where Lewisian (NAC) Archaean basement is present, from southern terranes where NAC rocks are absent. Faulting was initiated in the Caledonian (428 \pm 1.9 ; Stewart et al., 2001 and references therein) and involved a sinistral strikeslip movement of at least $200 \mathrm{~km}$. The GGF was reactivated with comparatively minor dextral motion $(10-18 \mathrm{~km})$ during the Cenozoic due to differential spreading from the opening of the Atlantic (Le Breton et al., 2013). Various seismic tomographic studies and deep seismic surveys, including the north-south LISPB survey line of 
Barton et al. (1992) are ambiguous in their exact details of a NAC or Lewisian cut-off south of the GGF. For this reason, our xenolith localities have focused on sites north of the GGF.

Xenolith suites from the Northern Highland terrane were entrained by Permo-Carboniferous intraplate silica-poor mafic dykes (basanite, melanephelinite and monchiquites), formed by tectonic decompression during continental extension (Kirstein et al., 2006). These dykes have ocean island basalt (OIB)-like mantle source compositions (Upton et al., 2004; Kirstein et al., 2006). While debate continues about the involvement of a mantle plume during Permo-Carboniferous rifting, He isotope data from the Scottish mantle lithosphere (including Streap Com'laidh xenoliths) do not support the hypothesis of involving a mantle plume (Kirstein et al., 2004) and instead suggests that magma was generated as a complex response to tectonic collapse of the Variscan Orogen (Kirstein et al., 2004 and references therein). An overview of this period of magmatic activity in Scotland can be found in Upton et al. (2004).

Most recently, the North Atlantic Igneous Province (NAIP) erupted as a widespread continental flood basalt event formed by the impingement of the Icelandic mantle plume beneath overlying lithosphere. Active continental rifting was initiated at $\sim 62 \mathrm{Ma}$ in the UK, Greenland and Baffin Island, and ultimately led to the opening of the Atlantic Ocean (Saunders et al., 1997). The British Palaeogene Igneous Province is part of the earliest magmatic expression in the NAIP and is developed through the Hebrides, the west coast of Scotland and Northern Ireland (Saunders et al., 1997).

The map in Fig. 2 highlights sites of xenolith suites in Scotland, including the three localities used in this study: Loch Roag (LR), Streap Com'laidh (STP) and Rinibar (RNB). These three localities were selected for their large and comparatively fresh peridotite mantle xenoliths, which yield sufficient material to process for whole-rock chemical analyses alongside mineral chemistry studies. All three xenolith localities are on the north side of the GGF, and thus are the most likely to have sampled the margin of the NAC. All of the mantle xenoliths studied are spinel lherzolites (stable at depths of 55-60 km; Griffin and O'Reilly, 1987). No garnet-peridotite xenoliths are recorded in Scotland suggesting that the deeper lithospheric root beneath the Scottish portion of the NAC has been lost during multiple tectonic events (e.g. Menzies and Halliday, 1988). A similar apparent loss of deep cratonic keel is described for the Labrador portion of the NAC, for which a cratonic rifting model was proposed (see Tappe et al., 2007). However, while a deep (garnet- or diamond-bearing) cratonic lithospheric mantle keel may be lacking in Scotland, the spinel lherzolites xenoliths from terranes north of the GGF represent the shallow regions of this cratonic SCLM (see Upton et al., 2011 and references therein). These localities provide an opportunity to investigate the pre-Mesozoic shallow lithospheric mantle, as entrained in basaltic magmatism rather than kimberlites (Bonadiman et al., 2008). By contrast the Loch Roag xenolith suite is entrained in an Eocene monchiquite dyke (Faithfull et al., 2012) and represents mantle potentially modified by the Icelandic plume. A description of each xenolith locality can be found in the following subsections, summarized in Table 1.

\section{Loch Roag, Isle of Lewis (Hebridean terrane)}

The $70 \mathrm{~cm}$ wide monchiquite dyke near Loch Roag (Isle of Lewis) cross-cuts Archaean Lewisian gneisses and contains a suite of upper mantle and crustal xenoliths and xenocrysts. Recent Ar-Ar age determination has confirmed this dyke to be midEocene in age (45.2 $\pm 0.2 \mathrm{Ma}$; Faithfull et al., 2012) and is therefore the youngest known magmatic intrusion in the UK. The xenolith/xenocryst assemblage of the Loch Roag dyke is unusual in comparison to elsewhere in the UK and Europe (Upton et al., 1983). It comprises a diverse range of lithologies and megacrysts; including spinel lherzolites, glimmerites, anothosites/anorthoclasites, gabbros and syenite xenoliths, and phlogopite 'books', apatite and corundum xenocrysts (Upton et al., 1983, 1999, 2011; Hunter and Upton, 1987; Menzies et al., 1987; Menzies and Halliday, 1988; Long et al., 1991). Previous studies on the spinel lherzolites were concerned with the isotopic composition and mineral chemistry of the major rock-forming minerals (see Upton et al., 2011 and references therein). New Re-Os whole-rock isotopic data for a Loch Roag spinel lherzolite are also available in Hughes et al. (2014) (see Table 1). Overall, the spinel lherzolites are granoblastic, porphyroblastic to sub-equigranular with crystal sizes typically ranging from $200 \mu \mathrm{m}$ to $1 \mathrm{~mm}$ in size. Porphyroblasts of orthopyroxene, up to $10 \mathrm{~mm}$ wide, are also common. Spinel grains appear 'corroded' and are intergrown at the rim by anorthoclase and/or anorthoclase-clinopyroxene (Na-enriched) 'symplectites' (Hunter and Upton, 


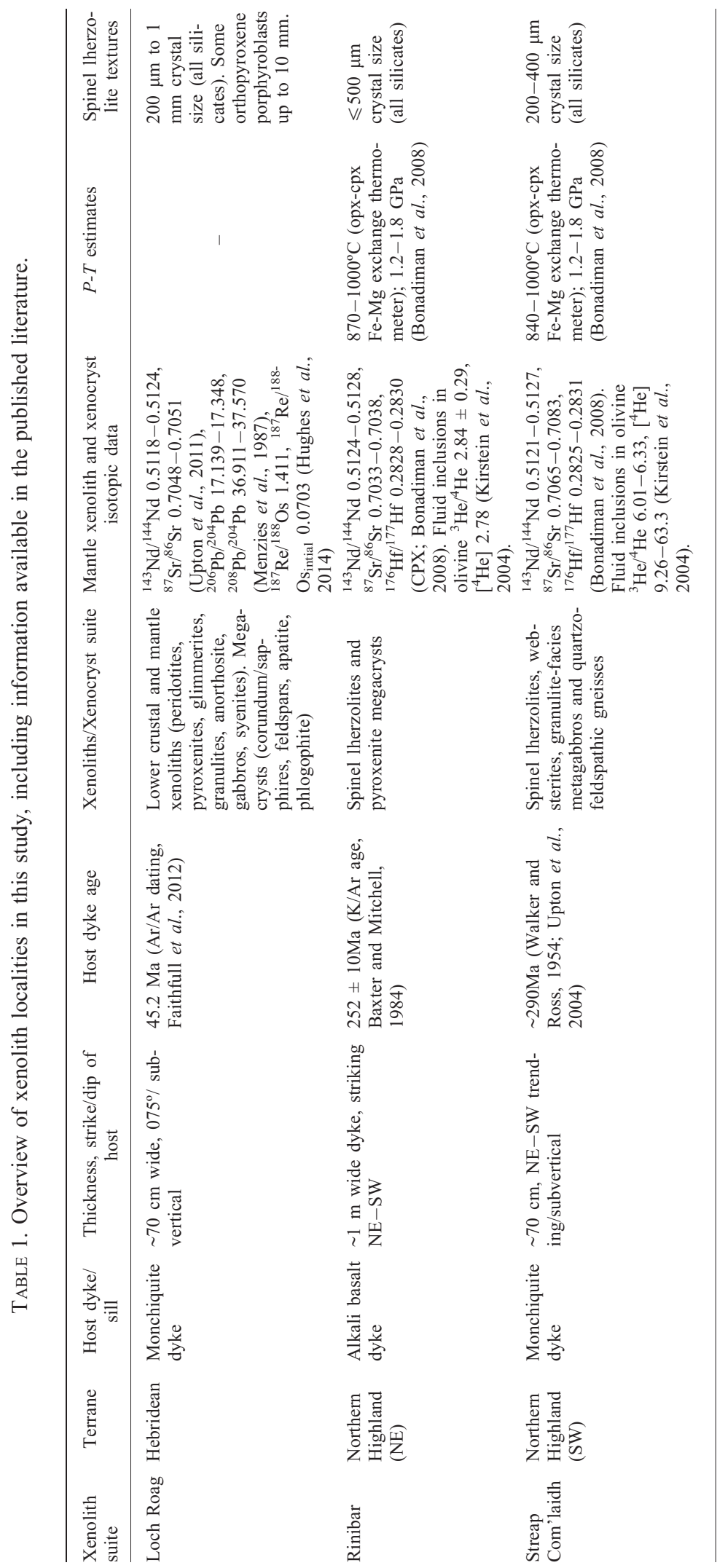


1987; Upton et al., 2011). Spinel lherzolite xenoliths typically have an oxidized or altered green-orange-brown 'halo' (cm-scale) around their rim (in contact with the host dyke) with unaltered or 'fresh' grey-coloured peridotite at the xenolith core (e.g. Fig. $3 a-b$ ). A suite of bright apple-green clinopyroxene-rich xenoliths (from here on referred to as 'green clinopyroxenites'; Fig. $3 c$ ) is
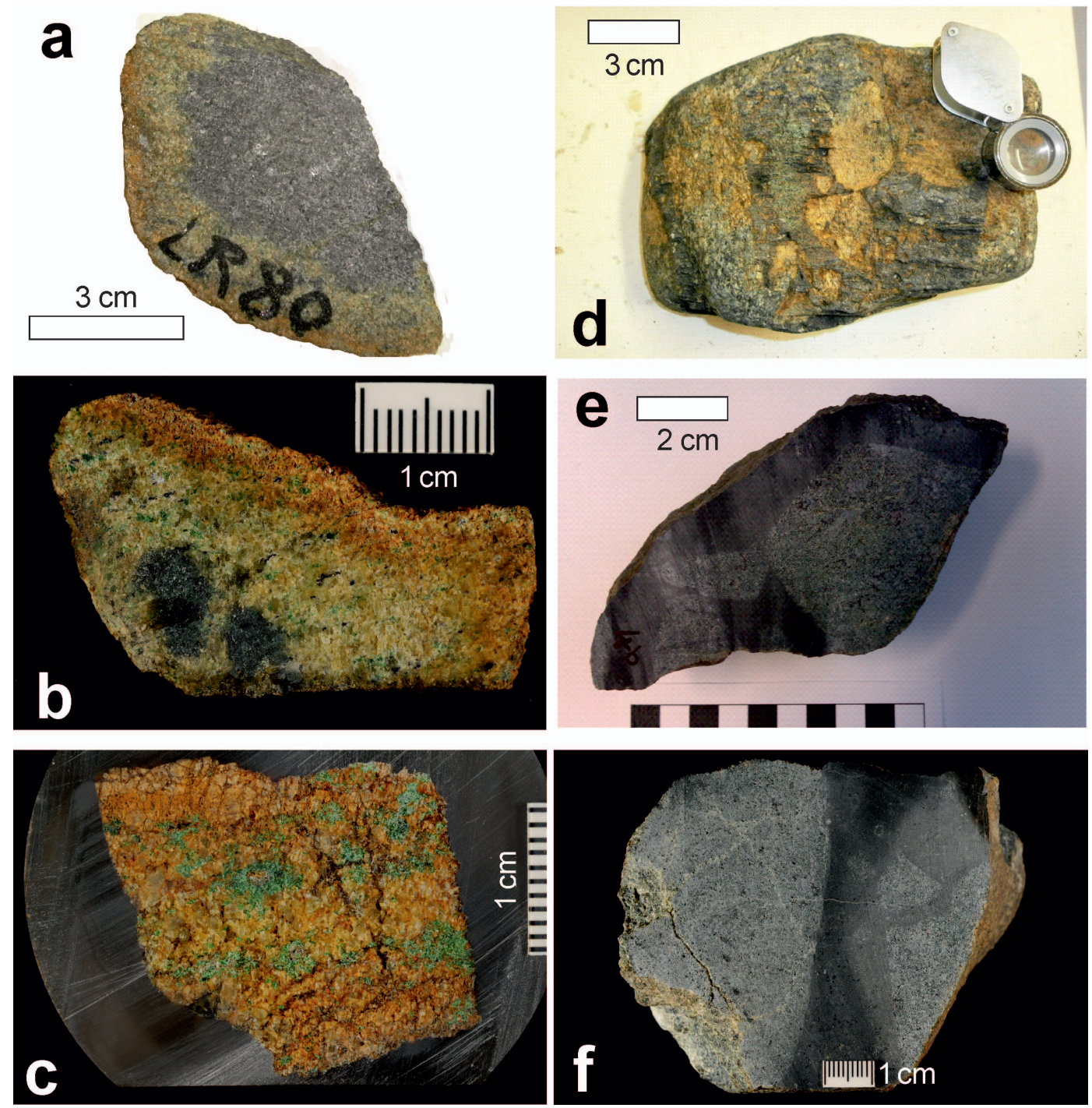

FIG. 3. Hand-sample photographs of xenolith slices, xenoliths, or xenoliths in a dyke. (a) Slice of LR80 (Loch Roag spinel lherzolite) showing green-orange-brown 'halo' of oxidation and alteration surrounding grey 'fresh' peridotite interior. (b) Slice of LR90 (Loch Roag spinel lherzolite), showing similar features to $(a)$, but with a greater thickness of the oxidized 'halo'. (c) Chip of LR100 (Loch Roag green clinopyroxenite) mounted in an epoxy resin block (unpolished) showing thick 'stringers' or 'veins' of apple green clinopyroxene through brown-orange nodules of olivine and chromite. (d) Weathered surface of hand sample G8 (Rinibar spinel lherzolite) with multiple peridotite xenoliths (weathered tan-brown). (e) Cut surface of hand sample of R2 (Rinibar spinel lherzolite) xenolith in alkali basalt dyke. $(f)$ Cut surface of hand sample ST5 (Streap Com'laidh spinel lherzolite) xenoliths in darker alkali basalt dyke material. 
present at Loch Roag. These consist of granular olivine and orthopyroxene, with rare chromite, but are dominated by granular polycrystalline green clinopyroxene.

\section{Rinibar, South Ronaldsey, Orkney Isles (Northern Highland terrane, northeast)}

The Rinibar xenolith locality is an $\sim 1$ m wide alkali basalt dyke, cross-cutting Devonian sandstones (UK grid reference [ND 412 929]). The xenolith suite comprises spinel lherzolites, which have been subjected to partial secondary hydration of ferromagnesian silicates along parallel fracture sets (such that xenoliths appear tanbrown; Fig. $3 d$ ) and have minor veining by calcite, magnetite and clays. The suite also includes clinopyroxene megacrysts. The host dyke is dated by whole-rock K-Ar methods at $252 \pm 10 \mathrm{Ma}$ (Baxter and Mitchell, 1984). Xenoliths from Rinibar have been investigated previously for their silicate and spinel traceelement compositions, in addition to whole-rock $\mathrm{Sr}, \mathrm{Nd}$ and $\mathrm{Hf}$ isotopes (Bonadiman et al., 2008) (see Table 1). The spinel lherzolites still largely record protogranular textures (Bonadiman et al., $2008)$ with fine-grained $(\leqslant 0.5 \mathrm{~mm})$ silicates and spinels and protogranular to porphyroclastic textures (Mercier and Nicholas, 1975). However, the mineral crystal sizes are typically less than what would be expected in cratonic peridotite xenoliths $(2-10 \mathrm{~mm}$; Pearson et al., 2003 and references therein).

\section{Streap Com'laidh, near Glenfinnan (Northern Highland terrane, southwest)}

The $70 \mathrm{~cm}$ wide host monchiquite dyke is part of a northeast-southwest trending swarm which intrudes Moinian metasediments (UK grid reference [945 844]), and is thought to date from $\sim 290 \mathrm{Ma}$ (Walker and Ross, 1954; Praegel, 1981; Upton et al., 1983, 2004). The mantle xenolith suite is dominated by spinel lherzolites, but also includes websterites (Bonadiman et al., 2008 and references therein). Whole-rock compositions of the Streap Com'laidh spinel lherzolites have been presented previously in Praegel (1981). Wholerock and clinopyroxene $\mathrm{Sr}, \mathrm{Nd}$ and $\mathrm{Hf}$ isotopes, and silicate mineral trace-element compositions have been reported in Bonadiman et al. (2008) (see Table 1). The Streap Com'laidh spinel lherzolites show primitive granoblastic mantle textures, similar to Rinibar lherzolites, however silicates (especially olivine) are notably fresher and the xenoliths as a whole have undergone significantly less alteration and serpentinization (e.g. Fig. $3 e-f$ ). Lherzolites from Streap are protogranular but distinctly fine grained $(200-400 \mu \mathrm{m})$; olivine crystals are fresh, $<0.5$ $\mathrm{mm}$ with rounded grain boundaries and occasionally with undulose extinction. Orthopyroxene may also be kinked (Bonadiman et al., 2008).

\section{Analytical techniques and methodology}

\section{Petrography and mineral chemistry analysis}

Petrographic studies on polished thin sections were employed to identify xenolith textures. Further thin-section examination, mapping and quantitative microanalysis was carried out on a Cambridge Instruments S360 scanning election microscope (SEM) at Cardiff University. Quantitative microanalyses were obtained using an Oxford Instruments INCA Energy EDX analyser attached to the SEM, with operating conditions set at $20 \mathrm{kV}$ and specimen calibration current of $\sim 2 \mathrm{nA}$ at a fixed working distance of $25 \mathrm{~mm}$. Analytical drift checks were carried out every $2 \mathrm{~h}$ using the Co reference standard and a comprehensive suite of standards from MicroAnalysis Consultants Ltd were used to calibrate the EDX analyser.

Laser ablation-inductively coupled plasmamass spectrometry (LA-ICP-MS) was performed on clinopyroxenes at Cardiff University. The system comprised a New Wave Research UP213 laser system coupled to a Thermo X Series 2 ICP-MS. The laser was operated using a frequency of $20 \mathrm{~Hz}$ that developed pulse energy of 1-2 $\mathrm{mJ}$ for a $40 \mu \mathrm{m}$ diameter beam. Samples were analysed using an acquisition time of $90 \mathrm{~s}$, comprising a $20 \mathrm{~s}$ gas blank, $60 \mathrm{~s}$ ablation and $10 \mathrm{~s}$ wash-out. Calibration of the ICP-MS was accomplished using the USGS glass standards BIR-1a and BHVO-2G with certified USGS basalt glass BCR-2G analysed as an unknown every 10-12 samples to check the accuracy of the analysis. A summary of the measured concentrations in the BCR-2g unknowns versus expected concentrations is given in Table A in the supplementary information which has been deposited with the Principal Editor of Mineralogical Magazine and is available from

www.minersoc.org/pages/e_journals/ dep_mat_mm.html.

The suite of isotopes analysed were ${ }^{23} \mathrm{Na}$, ${ }^{25} \mathrm{Mg},{ }^{29} \mathrm{Si},{ }^{39} \mathrm{~K},{ }^{44} \mathrm{Ca},{ }^{47} \mathrm{Ti},{ }^{51} \mathrm{~V},{ }^{52} \mathrm{Cr},{ }^{55} \mathrm{Mn},{ }^{60} \mathrm{Ni}$, ${ }^{71} \mathrm{Ga},{ }^{85} \mathrm{Rb},{ }^{88} \mathrm{Sr},{ }^{89} \mathrm{Y},{ }^{90} \mathrm{Zr},{ }^{93} \mathrm{Nb},{ }^{133} \mathrm{Cs},{ }^{137} \mathrm{Ba}$, 
${ }^{139} \mathrm{La},{ }^{140} \mathrm{Ce},{ }^{141} \mathrm{Pr},{ }^{146} \mathrm{Nd},{ }^{147} \mathrm{Sm},{ }^{153} \mathrm{Eu},{ }^{157} \mathrm{Gd}$, ${ }^{159} \mathrm{~Tb},{ }^{163} \mathrm{Dy},{ }^{165} \mathrm{Ho},{ }^{166} \mathrm{Er},{ }^{169} \mathrm{Tm},{ }^{172} \mathrm{Yb},{ }^{175} \mathrm{Lu}$, ${ }^{178} \mathrm{Hf},{ }^{181} \mathrm{Ta},{ }^{208} \mathrm{~Pb},{ }^{232} \mathrm{Th}$ and ${ }^{238} \mathrm{U}$. Calcium concentrations of clinopyroxene cores and rim, as determined using SEM, were used as an internal standard to correct for matrix and drift effects in the calculation of the trace-element abundances. Blank correction, drift corrections and conversion of ICP-MS output data (counts/s) to concentrations (wt.\% or $\mu \mathrm{g} / \mathrm{g}$ ) were accomplished using Thermo Plasmalab software. Full data for majorand trace-element concentrations in clinopyroxene from the xenolith samples are given in Table B of the supplementary information (deposited and available from

www.minersoc.org/pages/e_journals/ dep_mat_mm.html).

\section{Whole-rock sample preparation and analysis}

Mantle xenolith samples were provided by the British Geological Survey and Hunterian Museum (University of Glasgow). For whole-rock analyses this included seven separate xenoliths of $\sim 3-6 \mathrm{~cm}$ diameter from Loch Roag (e.g. Fig. $3 a-c$ ), two larger angular xenoliths $(10-20 \mathrm{~cm})$ from Rinibar, and five large xenoliths (ranging from 10 to $15 \mathrm{~cm}$ in diameter) from Streap Com'laidh (e.g. Fig. $3 e-f$ ). When cut, some of the Loch Roag peridotite xenoliths display dark green 'alteration' rims, with orange-brown vein-like infills. In one of these samples (LR80; Fig. 3a) a grey-black, visually 'unaltered' central zone in the xenolith was large enough to be extracted and analysed separately. Only xenoliths large enough for powdering were selected for whole-rock analysis but where material was limited, powdered samples weighed $>25$ g (typically $80-150 \mathrm{~g}$ for larger xenolith samples). The dykes hosting the xenolith suites were also analysed in order to compare the compositions of the dykes and xenoliths, and therefore, to assess if dyke material remained during xenolith sample preparation.

All samples were crushed to chips, either by hand (smaller samples) in a hardened steel pestle and mortar, or crushed through a hardened steel jaw crusher (larger samples). Gravels were then milled to a fine powder in agate planetary ball mills at Cardiff University. Major and trace elements were analysed by inductively coupled plasma optical emission spectrometry (ICP-OES) and inductively coupled plasma mass spectrometry (ICP-MS), respectively, at Cardiff University using methods and instrumentation described by McDonald and Viljoen (2006). Accuracy was constrained by analysis of the certified international reference materials JB1a, JB3, NIM-P, NIM-N, JA2 and JP1. Precision was estimated by repeat analysis of a sub-set of samples. Whole-rock geochemical results for all xenoliths and dykes analysed during this study are presented in Table 2 .

\section{Results}

\section{Petrography and accessory mineralogy}

Representative back-scattered electron (BSE) images obtained by SEM are presented in Figs 4-6. In lherzolites from Streap Com'laidh the effects of peripheral xenolith melting during entrainment in the host dyke are highlighted. This is manifest by $\mathrm{Al}-\mathrm{Mg}$ hercynite spinel melting reactions to produce 'disaggregated' chromite, which penetrates along silicate grain boundaries and into the host dyke (e.g. Fig. $4 a-b$ ). In some cases, tiny micron or sub-micron scale Ni-Fe sulfide droplets are associated (and entrained?) with the melted chromite (e.g. Fig. 4c). Elsewhere, partially melted clinopyroxene is also observed, however this is not restricted to the xenolith margins and is not obviously associated with any foreign melt ingress. Micron scale Ni-Fe sulfide droplets are also present at the clinopyroxene melting interface (Fig. 4d). In Rinibar xenoliths, silicates (especially olivine) are notably altered and hydrated - e.g. in serpentinized $\mathrm{Fe}$-oxide and $\mathrm{Ni}-\mathrm{Fe}$-sulfide droplet-bearing olivine of Fig. $5 a$. Melting reactions occur at the xenolith margins in contact with the host dyke, however these appear to re-anneal the xenolith, sealing it off at the rim such that serpentinized fractures are 'healed' (Fig. 5b). In some Rinibar samples, clinopyroxene contains elongate inclusions or 'lamellae' of chromite, which have then been cross-cut and fractured by serpentine-filled veinlets (Fig. 5c). Mg-Al spinel is absent in Rinibar, and instead the majority of spinel-group minerals in these xenoliths are chromite. In some cases, the xenoliths contain clinopyroxene, plagioclase and orthoclase different from the composition of the host dyke (Fig. 5d).

Apple-green polycrystalline clinopyroxenebearing xenoliths ('green clinopyroxenites') were also analysed from Loch Roag (Fig. 6). Clinopyroxene occurs as anastomosing green 'veins' and 'stringers' across these rocks (e.g. Fig. $3 c$ ). These xenoliths are highly friable and 


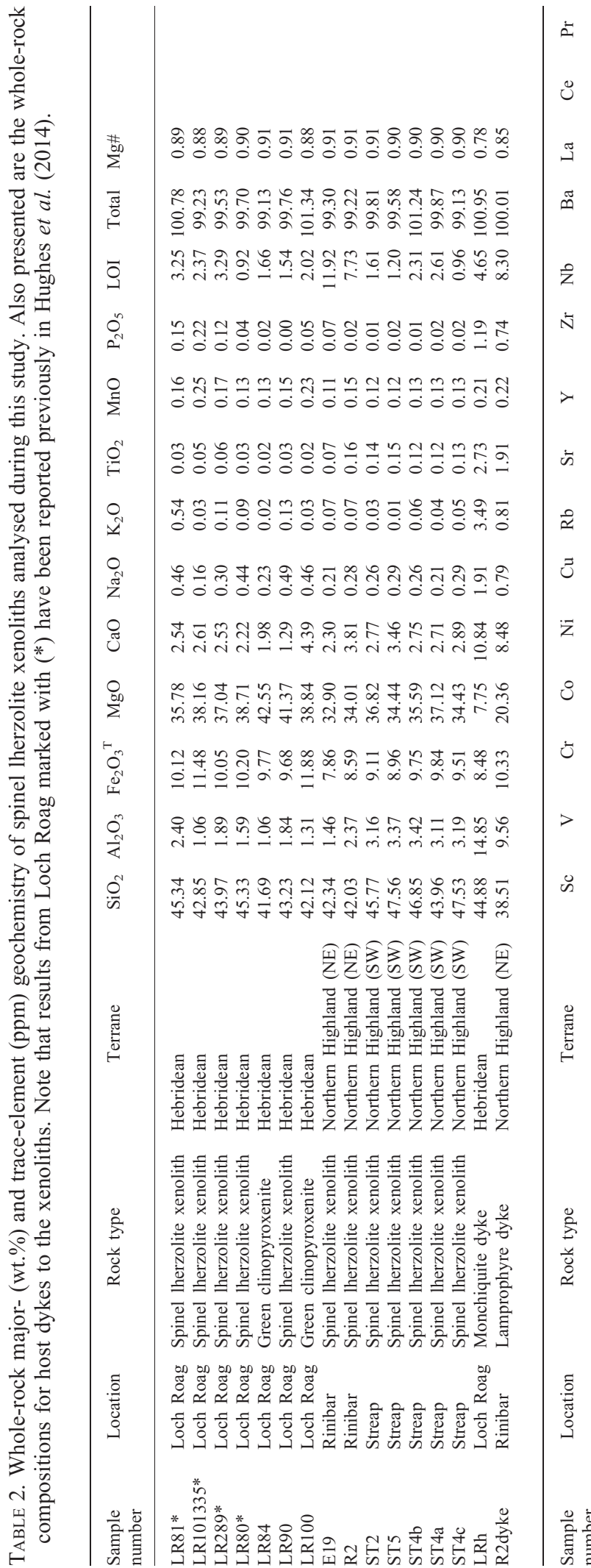

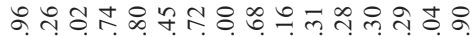

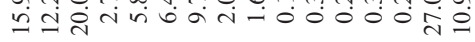

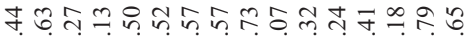

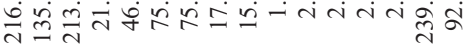

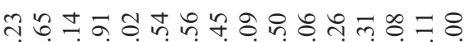

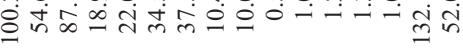

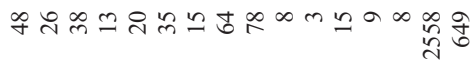

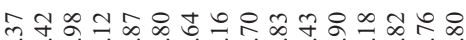
ڤं

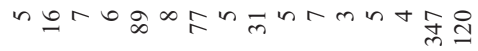

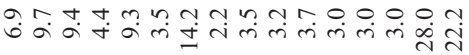

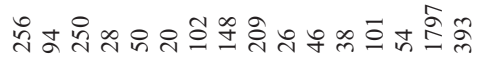
饵

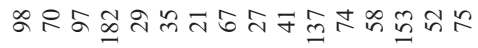

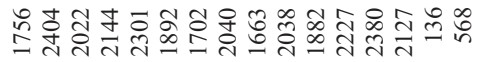

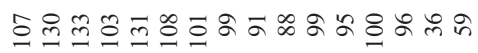

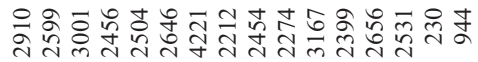

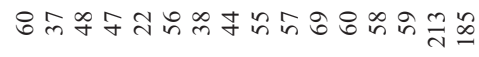

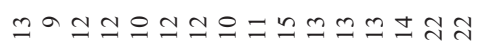

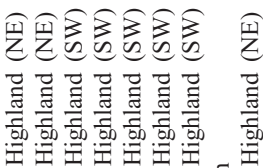

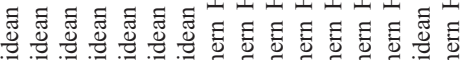

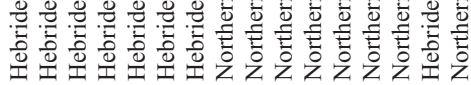

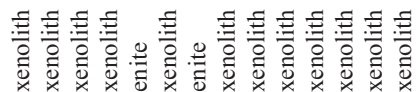

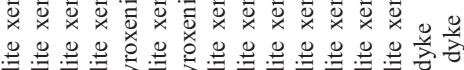

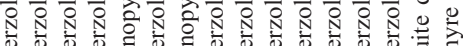

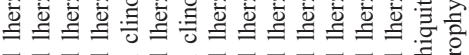

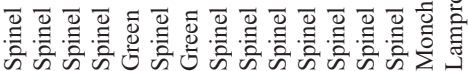

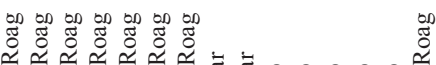

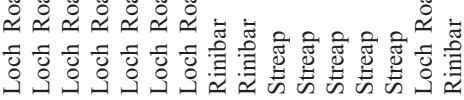
*

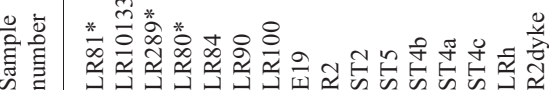




\begin{tabular}{|c|c|}
\hline$\supset$ & 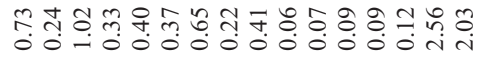 \\
\hline$\tilde{F}$ & 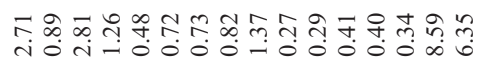 \\
\hline$\tilde{\sigma}$ & 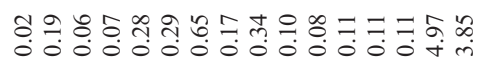 \\
\hline 生 & 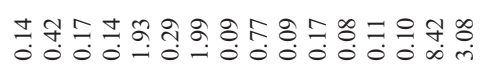 \\
\hline$\Xi$ & 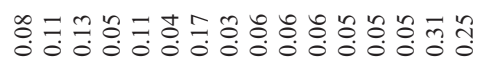 \\
\hline$\dot{خ}$ & 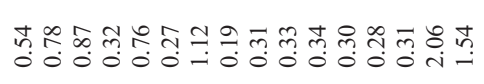 \\
\hline$\Xi$ & 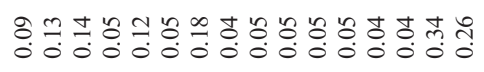 \\
\hline 牙 & 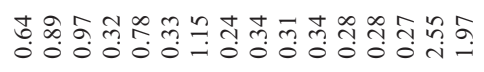 \\
\hline 오 & 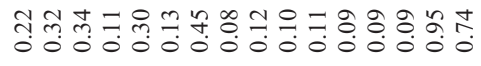 \\
\hline$\vec{a}$ & mे \\
\hline 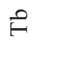 & 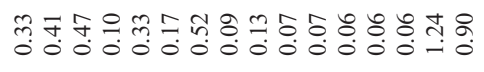 \\
\hline تூ & 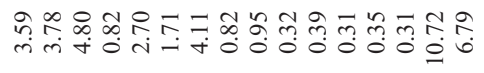 \\
\hline 馬 & 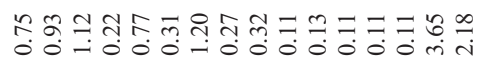 \\
\hline ణ & 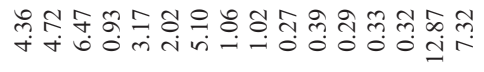 \\
\hline $\bar{z}$ & 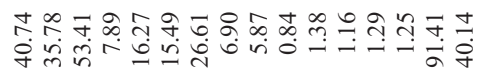 \\
\hline 惫 & 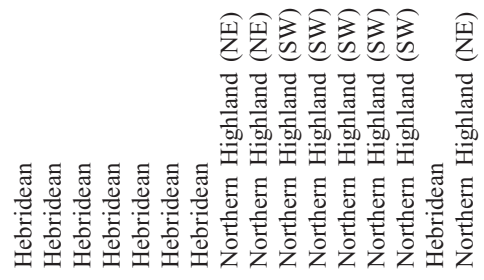 \\
\hline 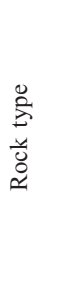 & 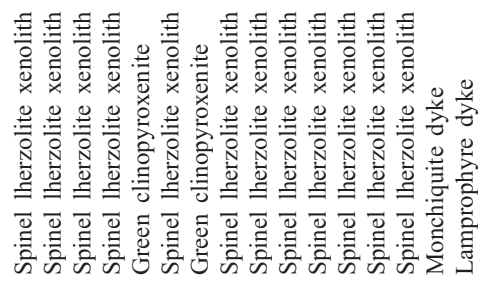 \\
\hline 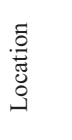 & 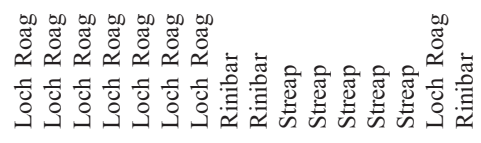 \\
\hline 品 & 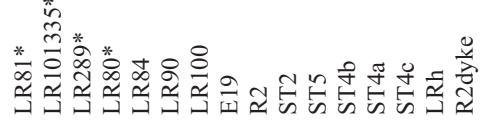 \\
\hline
\end{tabular}

show polycrystalline clinopyroxenes surrounding and including fine granular olivine and chromite crystals (Fig. $6 a, c, d$ ). Sulfides are extremely rare, in contrast with other Loch Roag spinel lherzolites and, where present, these consist of pentlandite and pyrrhotite only (Fig. 6b). Intriguingly, the clinopyroxene-rich specimens also retain white chlorite-filled veinlets (up to $1 \mathrm{~mm}$ wide) with minor phlogopite. Within these veinlets, chlorite has been overprinted by a $\mathrm{Ce}$ carbonate, possibly bastnäsite-(Ce) [i.e. $\left.(\mathrm{Ce}, \mathrm{La})\left(\mathrm{CO}_{3}\right) \mathrm{F}\right]$ which has infilled cleavage planes and fractures, sometimes associated with serpentine, along the chlorite 'books' (Fig. $6 e-f$ ).

\section{Whole-rock element abundances}

\section{Calculated normative mineral abundances}

The CIPW norm calculation results for mineral abundances based on anhydrous whole-rock major oxides (with $\mathrm{FeO}$ calculated from $\left.\left\{\mathrm{Fe}_{2} \mathrm{O}_{3}^{\text {measured }}-\left(\mathrm{TiO}_{2}+1.5\right)\right\} / 1.1\right)$, and $\mathrm{Sr}, \mathrm{Ba}$, $\mathrm{Ni}, \mathrm{Cr}$ and $\mathrm{Zr}$ concentrations based on the method of Rollinson (1993) (and references therein) are shown in supplementary Table C (deposited with the Principal Editor of Mineralogical Magazine and available from www.minersoc.org/pages/ e_journals/dep_mat_mm.html) and Fig. 7. Spinel lherzolite xenoliths from Loch Roag have the highest modal olivine contents (56-70 wt.\%), generally the lowest orthopyroxene abundances (0.8-24 wt.\%) and variable clinopyroxene content (up to 14 wt.\%). By contrast, xenoliths from the Northern Highland terrane have substantially lower olivine contents (39-59 wt.\%) and a narrower range of clinopyroxene abundances (4.5-7.4 wt.\%). Xenoliths from the Northern Highland terrane also have a higher calculated abundance of plagioclase feldspars (5.3-10.5 wt.\%) consistent with observed occurrences of 'corroded' spinels with a halo of anothosite symplectites in the Loch Roag xenoliths (e.g. Hunter and Upton, 1987).

\section{Major elements}

Bivariant plots of major-element oxides against $\mathrm{Al}_{2} \mathrm{O}_{3}$ content (as a proxy for the degree of depletion by partial melting) are presented in Figs $8 a-f$, in comparison to published xenolith data from the Greenlandic NAC (western and eastern coasts) and 'primitive upper mantle' (PUM; see figure caption for details). The $\mathrm{Al}_{2} \mathrm{O}_{3}$ contents of the Scottish peridotites range from compositions overlapping typical NAC (for Loch 

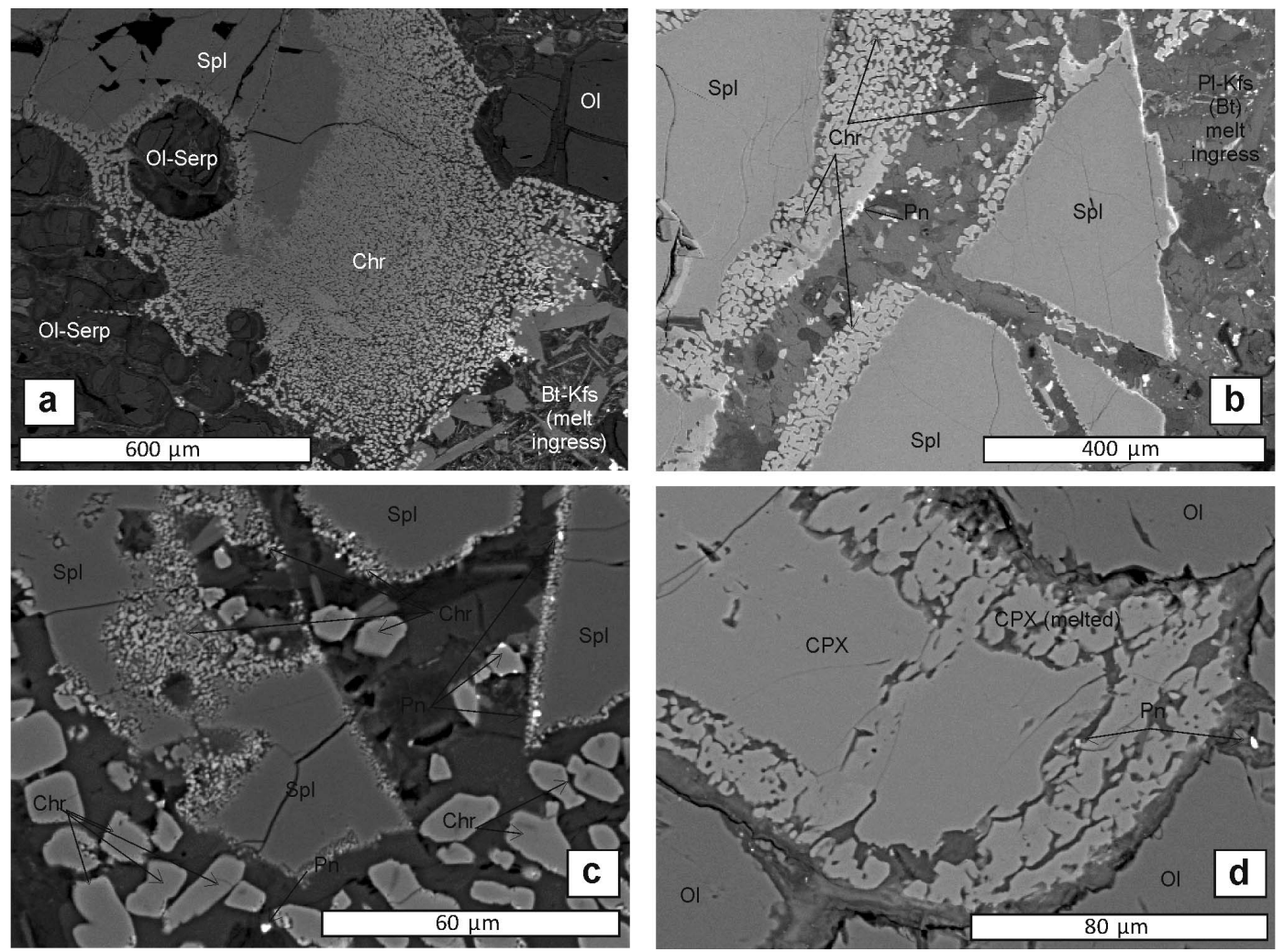

FIG. 4. Streap Coml'aidh BSE SEM images. (a) Al-Mg spinel reacting and melting to fine granular chromite at the spinel grain boundary and enclosing granular serpentinized olivine. The lower right hand corner of the image shows ingressed orthoclase and biotite-rich melt, possibly from the host dyke entraining the xenolith (sample 4a1). (b) Al$\mathrm{Mg}$ spinel reacting and melting to chromite. Note the tiny $\mu \mathrm{m}$-scale rounded pentlandite globules associated with spinel-chromite melting (sample 4a1). (c) Similar to (b) with Al-Mg spinel melting at the rim and forming granular chromite. Note the two crystal size populations of chromite: $>5 \mu \mathrm{m}$ granular, sub-euhedral chromite crystals $v s$. $\mu \mathrm{m}-$ scale rounded chromites. Both chromite populations are associated with $\mu \mathrm{m}$-scale pentlandite globules at crystal margins (sample 4a1). (d) Protogranular clinopyroxene and olivine. Clinopyroxene is melting to form finger-like crystals at its margins. This melt zone is again associated with $\mu \mathrm{m}$-scale pentlandite globules (sample 4a1). Mineral abbreviations: clinopyroxene (CPX), orthopyroxene (OPX), olivine (Ol), spinel (Spl), chromite (Chr), serpentine (Serp), pentlandite $(\mathrm{Pn})$,

Roag) to those approaching PUM (for Streap Com'laidh). The $\mathrm{Al}_{2} \mathrm{O}_{3}$ in Loch Roag varies by a factor of 3, whereas Streap Com'laidh has a tightly clustered $\mathrm{Al}_{2} \mathrm{O}_{3}$ ranging from $3.1-3.4$ wt.\% (anhydrous). Rinibar xenolith $\mathrm{Al}_{2} \mathrm{O}_{3}$ compositions in Fig. 8 are heavily dependent on their re-normalization to anhydrous values. In comparison to other NAC, the Scottish peridotites have notably lower $\mathrm{MgO}$ contents (35-43 wt.\% anhydrous), and higher $\mathrm{FeO}^{\mathrm{T}}$ (8-11 wt.\% anhydrous) and $\mathrm{CaO}$ (1.3-4.4 wt.\% anhydrous) - see Figs $8 a-c$. The $\mathrm{Na}_{2} \mathrm{O}$ contents of Loch Roag appear to form a bimodal distribution, with samples LR81, LR90, LR100 and LR80 having substantially higher concentrations than other Scottish or NAC peridotites (Fig. 8d). The $\mathrm{TiO}_{2}$ contents of the Scottish xenoliths are comparable to elsewhere in the NAC, with Streap Com'laidh forming a cluster along the chondrite $\mathrm{Al}_{2} \mathrm{O}_{3}-\mathrm{TiO}_{2}$ ratio (Fig. 8e). The MnO content is higher in two Loch Roag xenoliths (one spinel peridotite and one clinopyroxenite) than in other north Scottish xenoliths and other NAC xenoliths (Fig. 8f). Using elemental ratio plots of $\mathrm{Mg} / \mathrm{Si}, \mathrm{Al} / \mathrm{Si}$ and $\mathrm{Cr} / \mathrm{Al}$, the Scottish lherzolite xenoliths appear to continue along a 

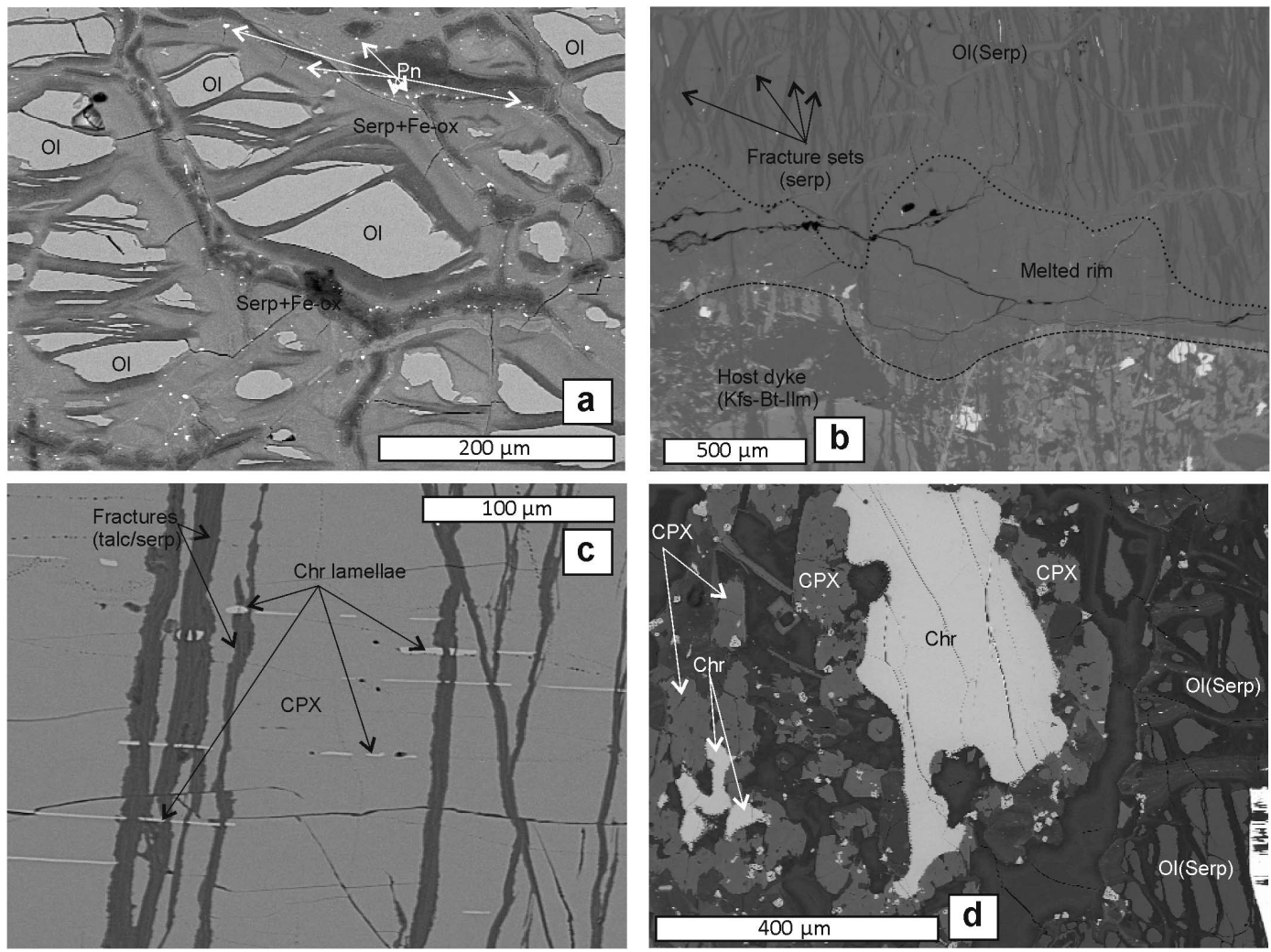

FIG. 5. Rinibar BSE SEM images. (a) Micron-scale pentlandite globules associated with serpentinized olivine (sample E19). (b) Image showing the edge of the xenolith in contact with the host dyke. The dyke consists of finely crystalline orthoclase, biotite and ilmenite and has a sharp contact with the xenolith. The inner portion of the xenolith (top of image) has widespread anastomosing fractures (serpentine and talc filled) but a melted and 'annealed' zone (free of fractures) sits in contact with the dyke (sample R2). (c) Clinopyroxene with a parallel set of serpentine and talc-filled fractures. Note the chromite lamellae throughout clinopyroxene, orthogonal to the fractures. Chromite lamellae are cross-cut by the fractures (sample R2). (d) Melt pocket consisting of chromite (with a very fine granular rim) and clinopyroxene with interstitial plagioclase and orthoclase feldspars. Serpentinized olivine on the right hand side of the image is protogranular. Mineral abbreviations: olivine (Ol), serpentine (Serp), clinopyroxene (CPX), dolomite (Dol), magnesite (Mag), plagioclase ( $\mathrm{Pl})$, chromite $(\mathrm{Chr})$, apatite (Ap), iron oxides (Fe-ox), orthoclase $(\mathrm{Kfs})$, biotite $(\mathrm{Bt})$, ilmenite (Ilm).

trend from the depleted cratonic peridotites of NAC towards PUM (Figs $8 g-h$ ).

\section{Trace elements}

Bivariant plots for trace elements in Fig. 9 are plotted vs. $\mathrm{Al}_{2} \mathrm{O}_{3}$. Scottish xenoliths have higher Sc concentrations than elsewhere in the NAC, reflecting higher modal clinopyroxene abundances (Figs $8 a$ and 6, respectively). Xenoliths from both the Hebridean and Northern Highland terranes have variable $\mathrm{Ni}$ contents (1500-2500 ppm; Fig. $9 b)$ but do not fall along a positive fractionation trend relating to partial melting, as seen for Greenlandic NAC peridotites at high $\mathrm{MgO}$ content (i.e. $\mathrm{Ni} / \mathrm{Mg}$ ratio is highly variable). Hence for the Scottish xenoliths and low-MgO NAC xenoliths, Ni concentration is predominantly controlled by sulfide abundance, rather than olivine. The Co content is similarly variable (Fig. $9 b$ ) however $\mathrm{Cu}$ abundances in the Scottish xenoliths are extremely variable and are several orders of magnitude greater than measured elsewhere in the Greenlandic NAC (Fig. 9d). The $\mathrm{Cu}$ appears to vary independently of $\mathrm{Al}_{2} \mathrm{O}_{3}$ (or $\mathrm{MgO}$ ) and probably tracks sulfides which are abundant in some xenoliths. In contrast, 

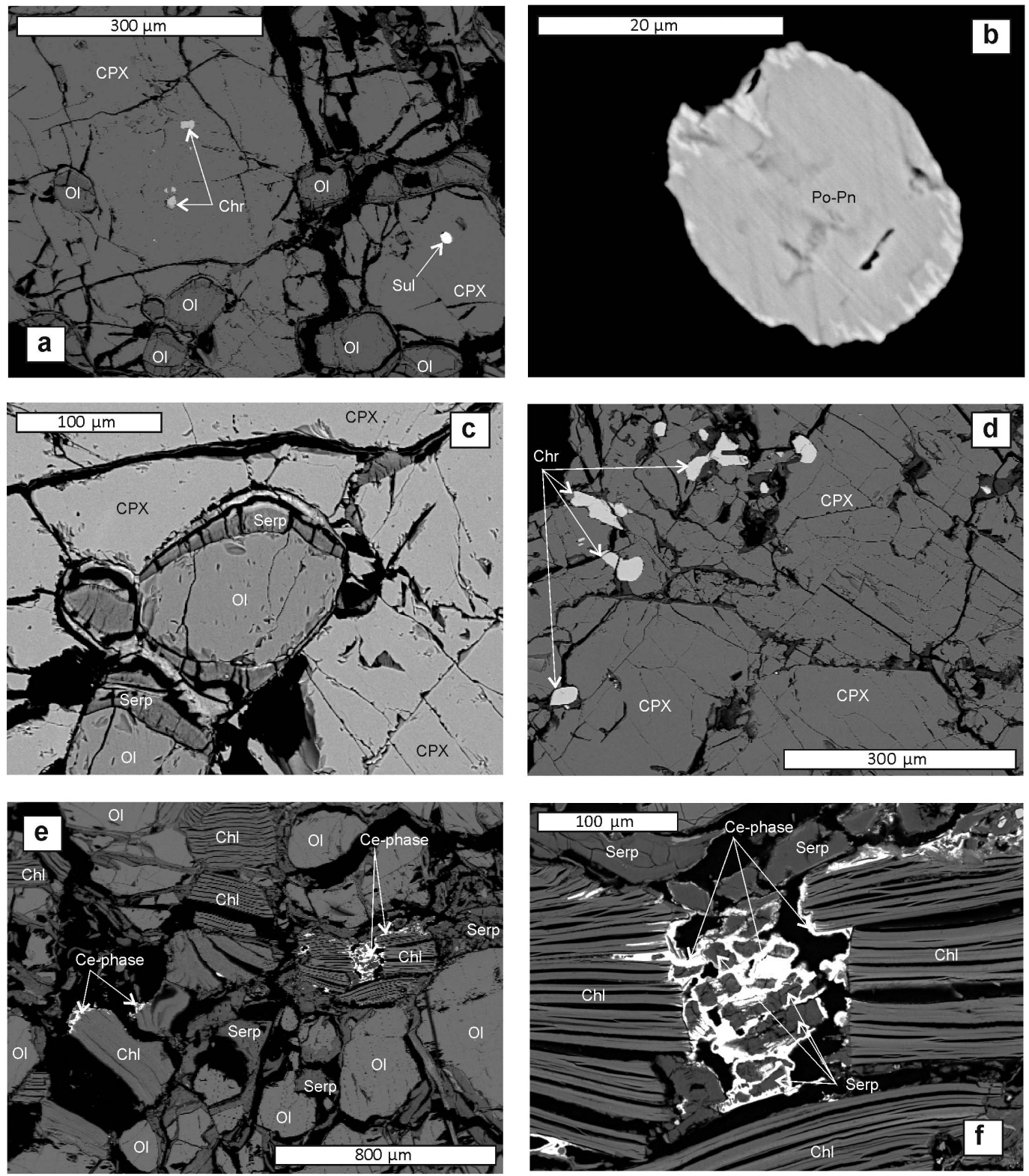

FIG. 6. Loch Roag green clinopyroxenite sample (LR84) BSE SEM images. (a) Anhedral clinopyroxene (apple-green in thin section) with small granular inclusions of olivine (partially serpentinized), chromite, and a rare rounded sulfide. (b) Close-up of the sulfide in $(a)$, showing the simple rounded shape and simple internal texture of pentlandite flames in pyrrhotite. (c) Close-up of partially serpentinized (at rim) olivine inclusions in clinopyroxene of $(a)$. (d) Irregular-shaped chromite inclusions in metasomatic clinopyroxene (apple-green in thin section). (e) Closeup of a section of a chlorite-filled veinlet that cross-cuts the xenolith. Books of chlorite within the vein are surrounded by granular serpentinized olivine. Chlorite books have a Ce mineral (carbonate or oxide) mineralizing along the chlorite cleavage and ends of crystals. $(f)$ Close-up of Ce mineral in $(e)$ showing chlorite book with $\mathrm{Ce}$ mineral encasing 'book ends' and granular serpentine (presumably olivine prior to serpentinization). Mineral abbreviations: olivine (Ol), clinopyroxene (CPX), chromite (Chr), sulfide (Sul), serpentine (Serp), chlorite (Chl), Cecarbonate/bastnäsite (Ce-phase), pentlandite (Pn), pyrrhotite (Po). 
TRACE ELEMENTS IN THE NAC LITHOSPHERIC MANTLE

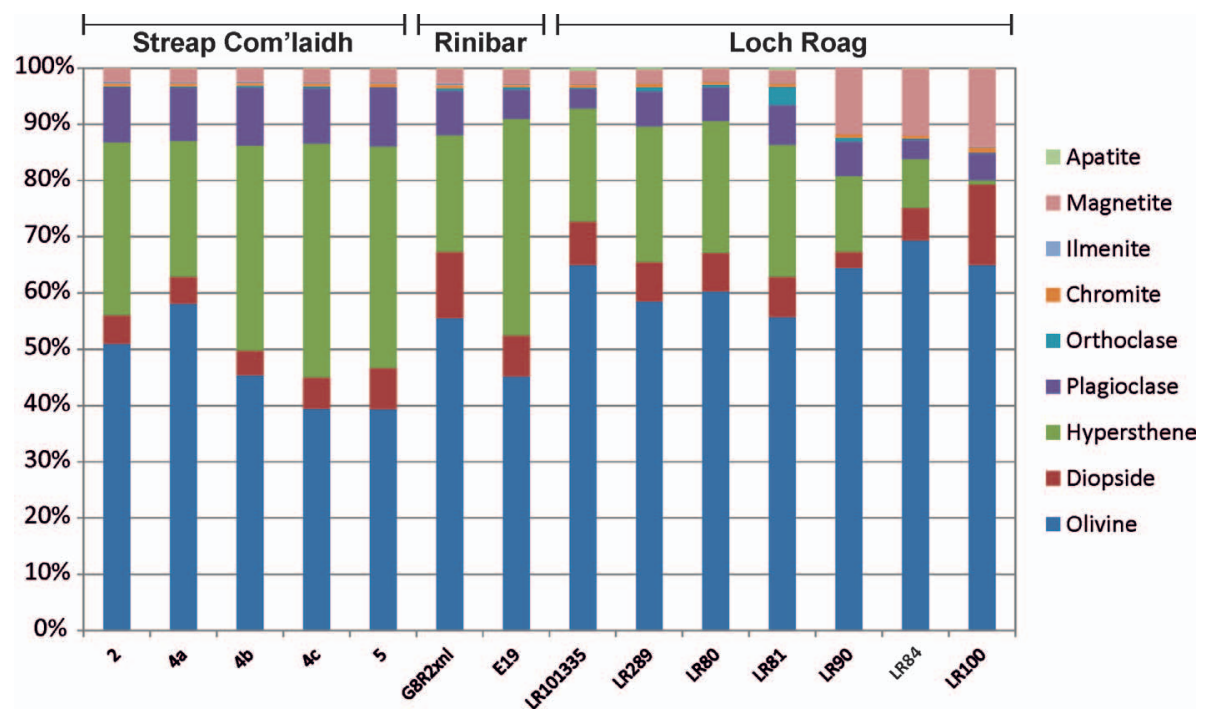

FIG. 7. Cumulative bar chart of modal mineral abundances in xenoliths analysed by whole-rock ICP-OES and ICPMS. Mineral abundances have been calculated by the CIPWnorm method.

V concentrations in Loch Roag xenoliths overlap Greenlandic NAC compositions (Fig. 9e), however $\mathrm{Cr}$ concentrations fall along a trend with $\mathrm{Al}_{2} \mathrm{O}_{3}$ which is distinct from other eastern NAC xenoliths (Fig. 9f).

The chondrite-normalized rare-earth element ( REE) abundances of the lherzolite xenoliths are compared with their host dykes in Fig. 10, and can be used to assess if the dyke has become mixed with the xenoliths either during entrainment itself, or sample crushing and homogenization. For Loch Roag, the host dyke has higher overall REE abundances, and notably lacks the negative $\mathrm{Eu}$ anomaly observed in the lherzolites. The overall REE abundances of the Rinibar dyke are an order of magnitude greater than those of the peridotite xenoliths analysed, and show subtle differences in light REE (LREE), middle REE (MREE) and heavy REE (HREE) patterns. Both Loch Roag and Rinibar xenoliths have highly fractionated REE abundances, such that $L R E E$ are elevated above $H R E E$, but by contrast the Streap Com'laidh xenoliths have comparatively flat $R E E$ patterns, such that chondrite-normalized $L R E E$ are only marginally more enriched than HREE. Further, HREE in Streap Com'laidh are inversely fractionated, increasing from Ho to Lu. Loch Roag spinel lherzolites have $(\mathrm{La} / \mathrm{Yb})_{\mathrm{N}}$ ranging from 40 to 127, Rinibar ranges 22 to 37 and Streap Com'laidh $(\mathrm{La} / \mathrm{Yb})_{\mathrm{N}}$ ranges from 1 to 3 .

The trace element compositions of the xeno- liths and host dykes can be further compared using the primitive mantle normalized multielement diagrams in Fig. 11. Incompatible element abundances are highly elevated in the host dykes of Rinibar and Loch Roag in comparison to the xenoliths. For certain key elements (e.g. $\mathrm{Nb}, \mathrm{Ta}, \mathrm{Sr}, \mathrm{P}, \mathrm{Zr}, \mathrm{Hf}$ and $\mathrm{Ti}$ ) the trace-element systematics between the dyke and corresponding xenoliths are entirely different, suggesting that host-dyke contamination was not an issue during sample preparation and/or xenolith entrainment in the alkali basalt dykes. Thus, the trace-element abundances and patterns in the xenoliths are primary features, largely unaffected by the host magmas.

Differences in the normalized trace-element patterns of Fig. 11 are seen between each Scottish xenolith suite. For example, all Loch Roag xenoliths (spinel lherzolites and clinopyroxenites) display consistent negative $\mathrm{Nb}, \mathrm{Ta}, \mathrm{Sr}$ and $\mathrm{Ti}$ anomalies, with most also having a notable negative $\mathrm{Zr}$ and $\mathrm{Hf}$ anomaly. The $\mathrm{Zr}$ and $\mathrm{Hf}$ abundances in Rinibar samples are strikingly different for the two xenoliths analysed (one has a negative Zr-Hf anomaly on Fig. $11 b$; the other lacks any anomaly), while the other trace elements on the diagram show more consistent features between Rinibar xenoliths. In the Streap Com'laidh suite, $\mathrm{Ba}$ is depleted in comparison to $\mathrm{Rb}$, and there is a consistent positive $\mathrm{Sr}$ anomaly, unlike any of the other suites. 

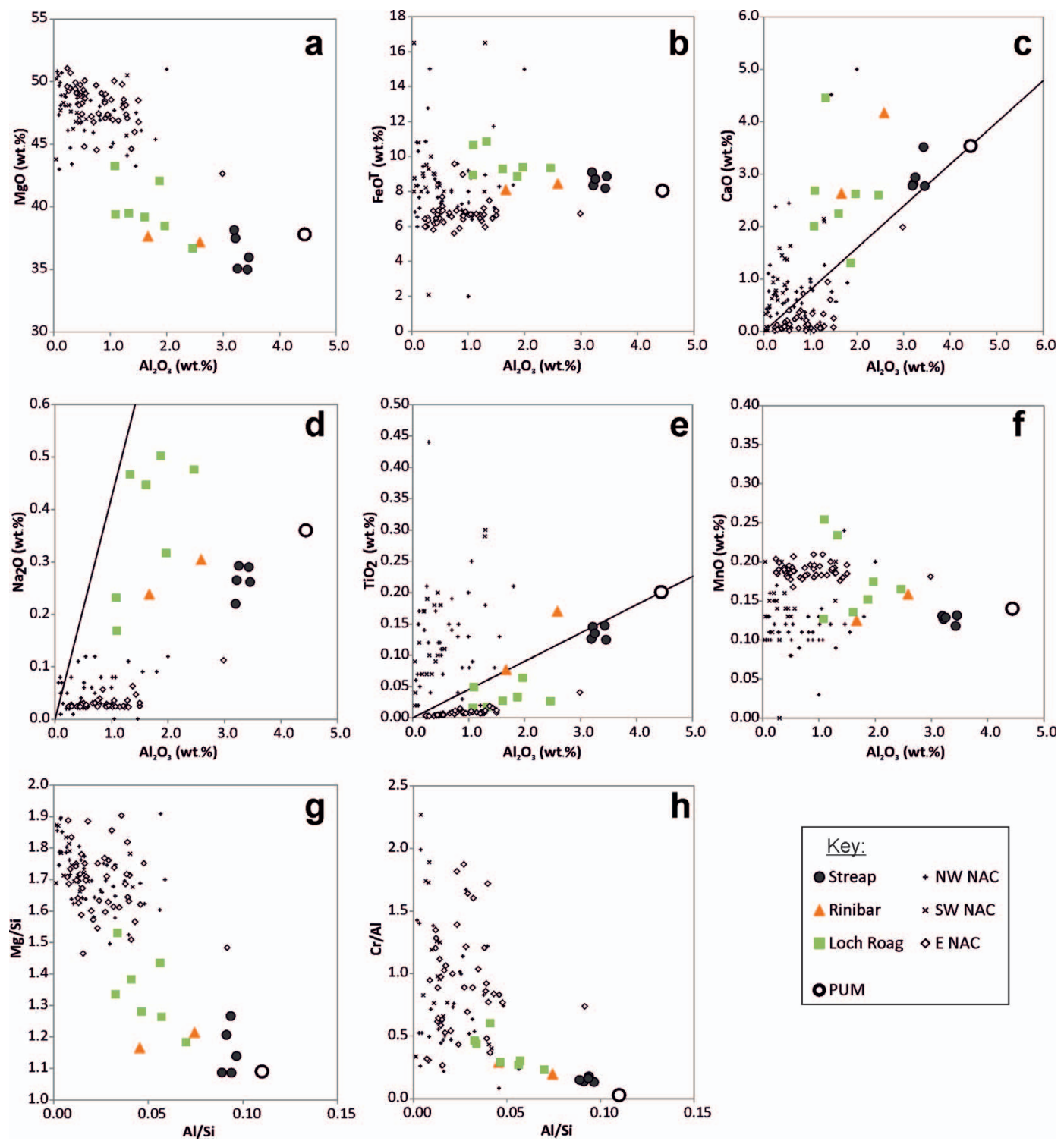

FIG. 8. Major-element binary plots (whole-rock) for Loch Roag, Streap Com'laidh and Rinibar spinel lherzolites (this study) in comparison to western ('NW NAC' and 'NW NAC'; from Wittig et al., 2010) and eastern ('E NAC'; from Bernstein et al., 1998) North Atlantic Craton mantle peridotites. Western NAC data are a mix of garnet and spinel peridotites. Eastern NAC data are all spinel peridotites. Black line indicates chondrite ratio of elements (as defined by McDonough and Sun, 1995).

FIG. 9 (facing page). Minor-element binary plots (whole rock) for Loch Roag, Streap Com'laidh and Rinibar spinel lherzolites (this study) in comparison to western ('SW NAC' and 'NW NAC'; from Wittig et al., 2010) and eastern ('E NAC'; from Bernstein et al., 1998) North Atlantic Craton mantle peridotites. Western NAC data are a mix of garnet and spinel peridotites. Eastern NAC data are all spinel peridotites. Black line indicates chondrite ratio of elements (as defined by McDonough and Sun, 1995). 
TRACE ELEMENTS IN THE NAC LITHOSPHERIC MANTLE
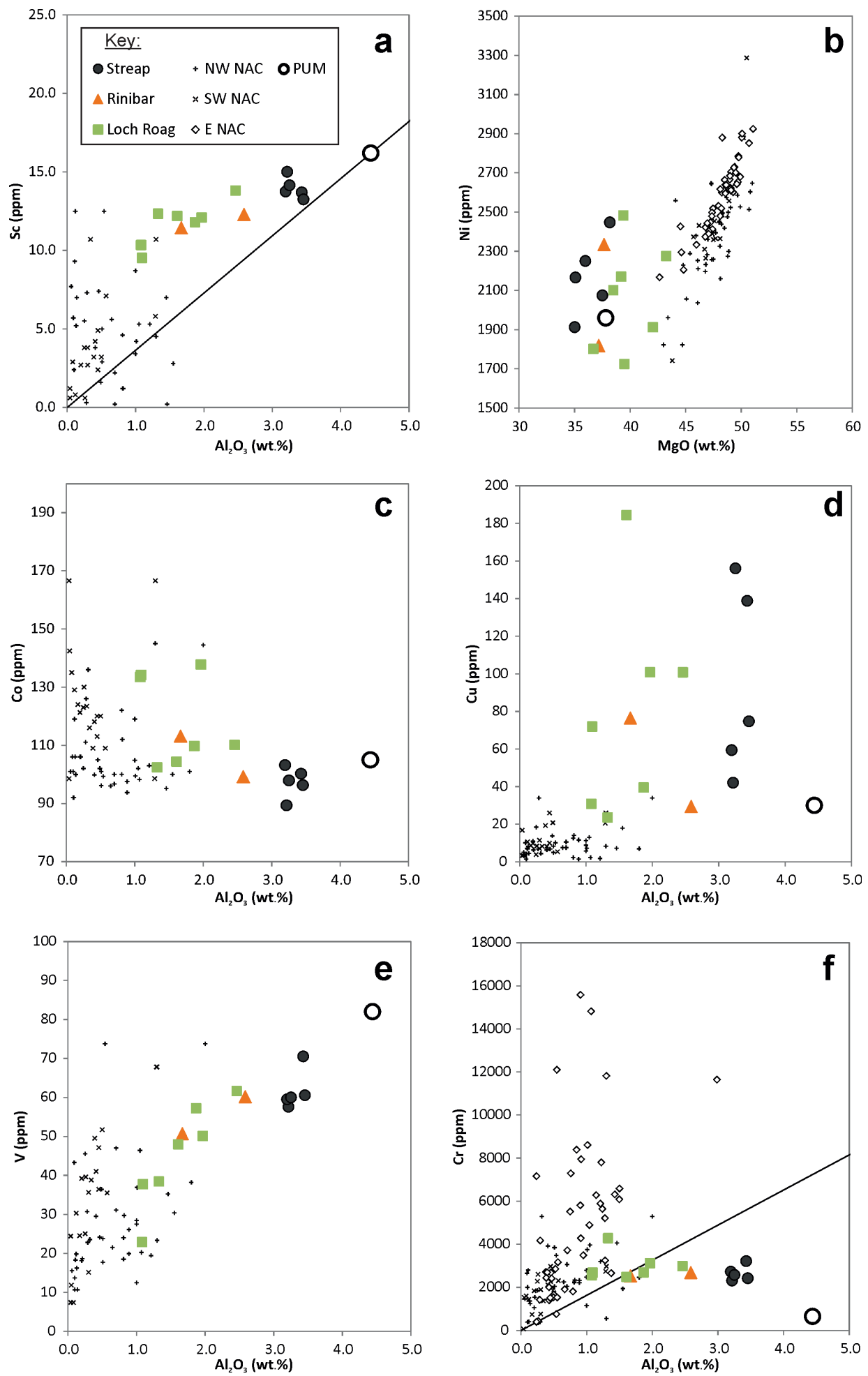
HANNAH S. R. HUGHES ET AL.
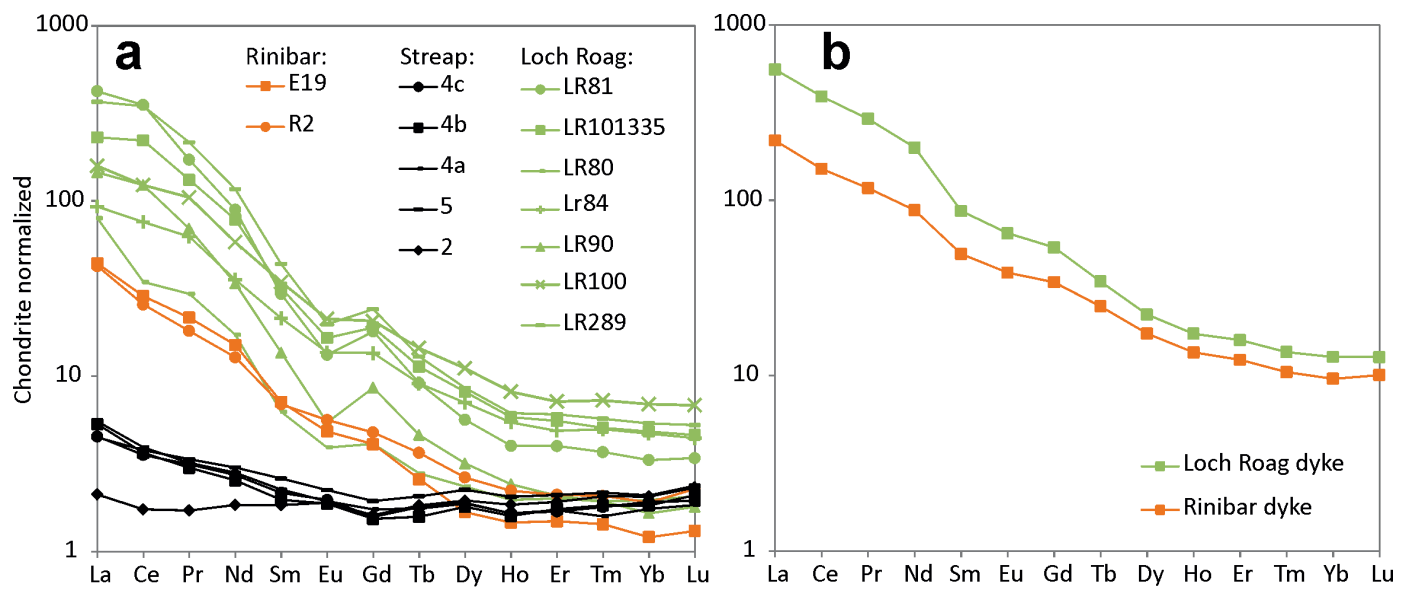

FIG. 10. Rare-earth element (REE) chondrite-normalized multi-element diagrams (whole rock) for Loch Roag, Streap Com'laidh and Rinibar spinel lherzolites $(a)$ and the host dykes to the xenolith suites $(b)$. Chondrite normalizing values from McDonough and Sun (1995).

\section{Clinopyroxene compositions}

Fully quantitative SEM energy dispersive spectroscopy (EDS) analyses were undertaken on a series of clinopyroxene crystals from various peridotite xenoliths of Loch Roag and Rinibar. Analogous clinopyroxene trace-element compositions from Streap Com'laidh were already given by Bonadiman et al. (2008). This was followed by LA-ICP-MS line analyses, and a selection of clinopyroxene major- and trace-element abundances are presented in Table 3 with full results available in the supplementary information (available from

www.minersoc.org/pages/e_journals/ dep_mat_mm.html).

Primitive mantle and chondrite normalized trace-element spidergrams and REE plots (Fig. $12 a-g$ ) show that clinopyroxenes from each xenolith sample analysed define distinct compositions. For example, Loch Roag sample LR80 is a comparatively 'fresh' spinel lherzolite with measured clinopyroxene compositions which have consistent negative anomalies for $\mathrm{Ba}, \mathrm{Nb}$, Ta, Sr, Hf and Ti (Fig. 12a). The REE profiles of clinopyroxene from this sample (Fig. 12b) show $L R E E$ enrichment, with $\mathrm{La}$ enriched over $\mathrm{Ce}$ and a flat HREE pattern. A striking observation for LR80 is the depletion of $\mathrm{Hf}_{\mathrm{N}}$ relative to $\mathrm{Zr}_{\mathrm{N}}$. Also noteworthy is the slight enrichment of $\mathrm{U}$ over $\mathrm{Th}$.

The trace element and REE profiles of pyroxenes in green clinopyroxenite xenoliths LR84 and LR100 (Figs $12 c-d, e$ and $g$ ) are markedly different from that of LR80 - negative anomalies for $\mathrm{Nb}, \mathrm{Ta}, \mathrm{Sr}$ and $\mathrm{Ti}$ are smaller than those in LR80. Additionally, $U$ and Th both show positive anomalies, again with $U$ enriched over Th, but these are less pronounced than in LR80. Most strikingly however, in both LR84 or LR100, there is no negative anomaly for either $\mathrm{Zr}$ or Hf; $\mathrm{Hf}_{\mathrm{N}}$ appears to be slightly enriched over $\mathrm{Zr}_{\mathrm{N}}$, in complete contrast to LR80. The REE profiles for clinopyroxene from both LR84 and LR100 are significantly elevated to normalized abundances greater than those in LR80, and the REE patterns define a convex shape for $L R E E$, such that $\mathrm{Ce}$ and Pr are enriched over La. Between LR84 and LR100 there are yet more subtle differences, e.g. between relative abundances of $\mathrm{Nb}$ to $\mathrm{Ta}$ and $\mathrm{Zr}$ to Hf. Lastly, the clinopyroxene REE compositions of Rinibar xenoliths are more akin to that of LR80 than other Loch Roag samples (Fig. 12g), although this is not strictly the case for all trace elements (Fig. 12f). For example, Rinibar clinopyroxenes have a positive $\mathrm{Sr}$ anomaly (rather than Loch Roag's negative one) and $\mathrm{Zr}$-Hf decoupling is even more pronounced, such that $\mathrm{Zr}_{\mathrm{N}}$ is notably enriched over $\mathrm{Hf}_{\mathrm{N}}$, but $\mathrm{Hf}$ is not depleted below PUM levels (Fig. 12f). Notably, none of the clinopyroxenes analysed from any of the Loch Roag xenoliths display a negative Eu anomaly, unlike those shown in some of the whole-rock REE diagrams (Fig. 10). In fact, some of the clinopyoxenes in LR80 have a slight positive Eu anomaly. Therefore the negative bulk Eu anomaly must relate to a different mineral phase (or phases) within the xenoliths. 

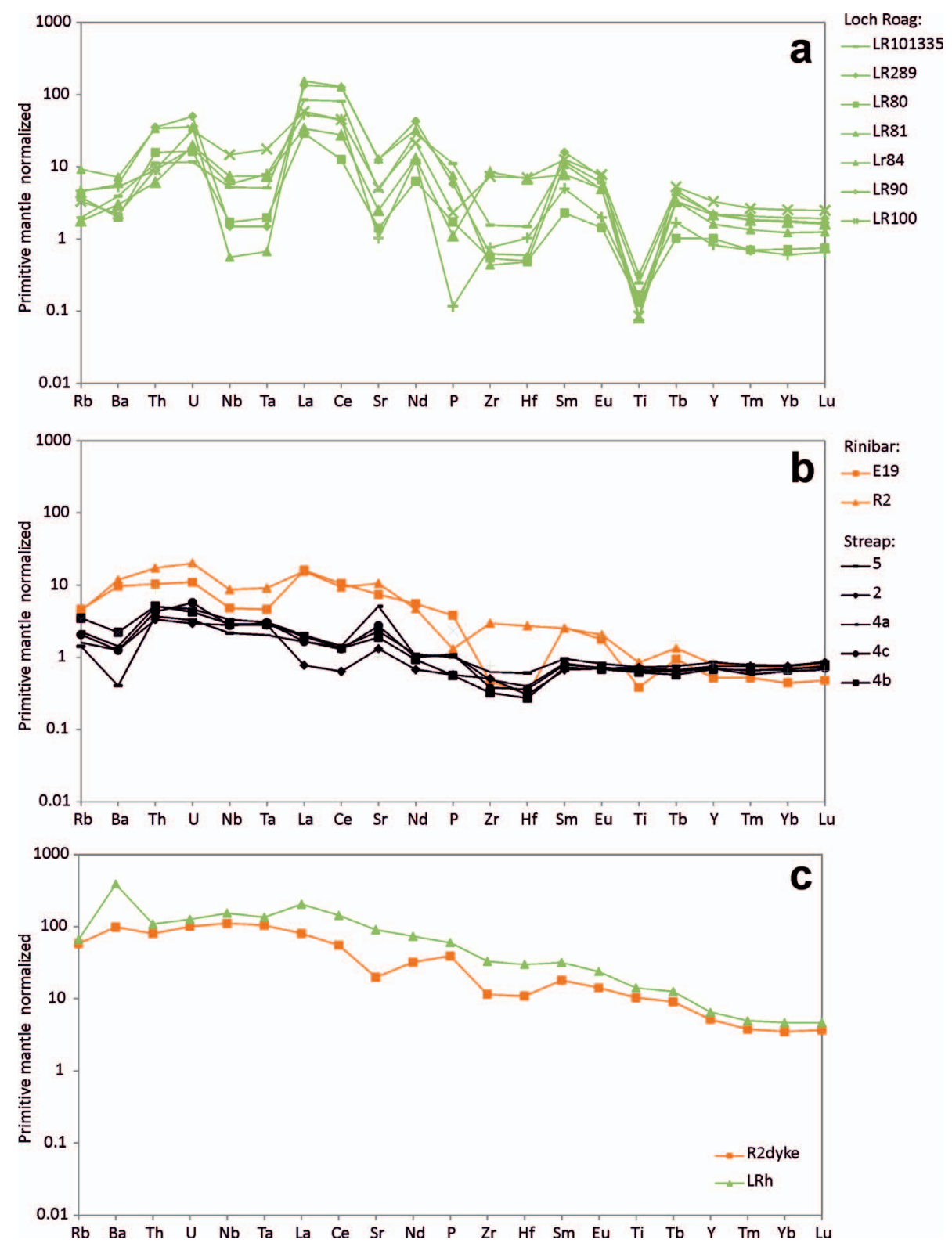

Fig. 11. Primitive mantle-normalized multi-element diagrams (whole rock) for Loch Roag (a), Streap Com'laidh and Rinibar spinel lherzolites $(b)$ and the host dykes to the xenolith suites $(c)$. Primitive mantle (pyrolite) normalizing values from McDonough and Sun (1995).

The trace-element characteristics of clinopyroxenes can be simplified in a series of binary diagrams, plotted in comparison with previous data for metasomatic clinopyroxenes from Rinibar and Streap Com'laidh (Bonadiman et al., 2008) - see Fig. 13. These provide clear separation of pyroxene compositions according to $(\mathrm{La} / \mathrm{Sm})_{\mathrm{N}}, \mathrm{Cr}, \mathrm{Y}$ and $(\mathrm{Zr} / \mathrm{Hf})_{\mathrm{N}}($ Fig. 13). Bonadiman et al. (2008) identified 'kimberlite' and 'carbonatite'-related metasomatic clinopyroxene compositions in Northern Highland terrane xenoliths. Secondary clinopyroxene 


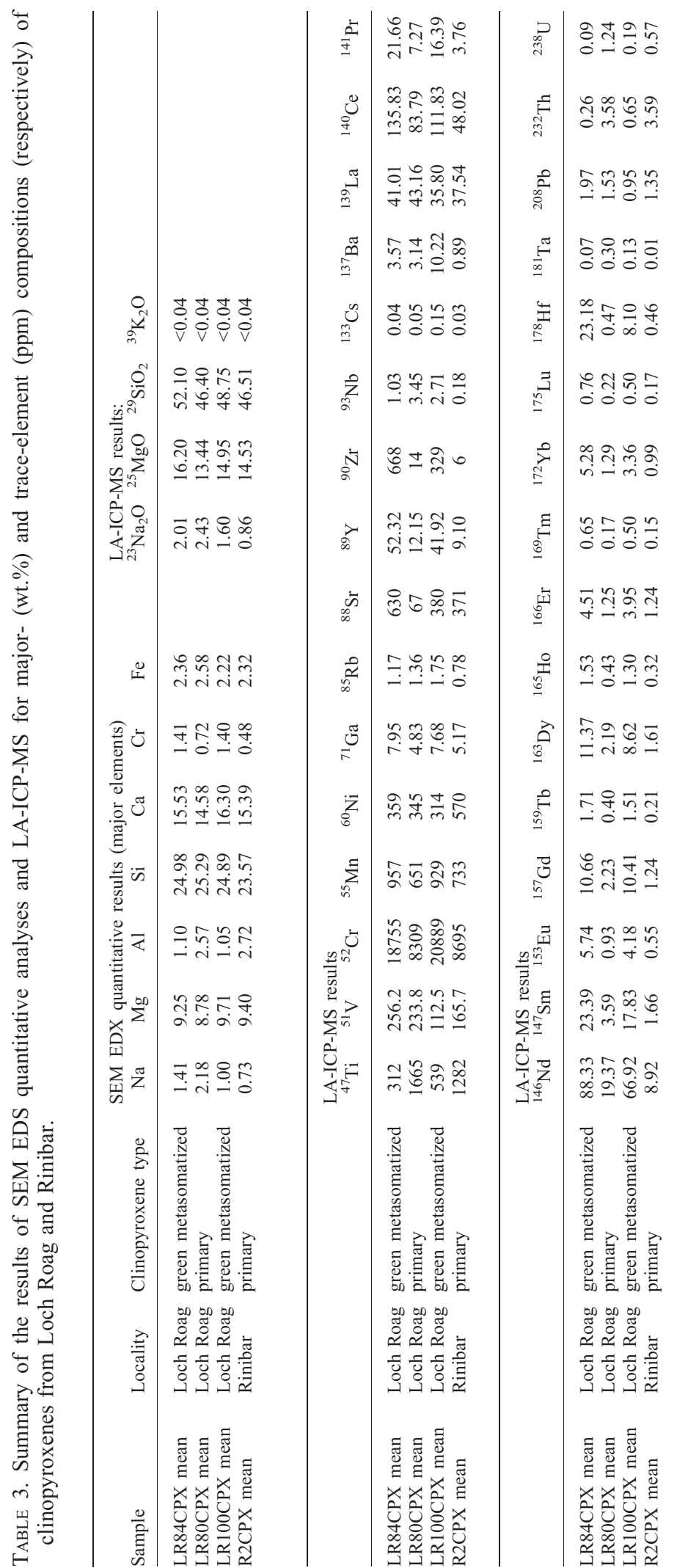




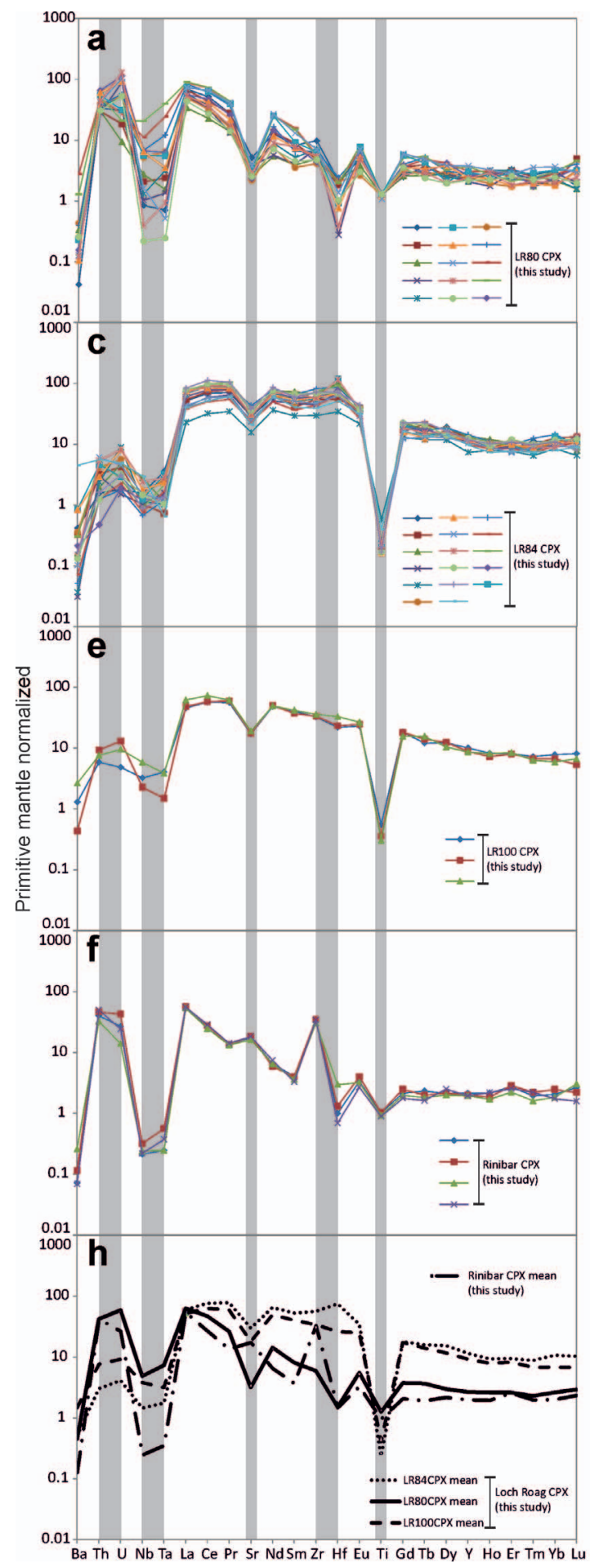

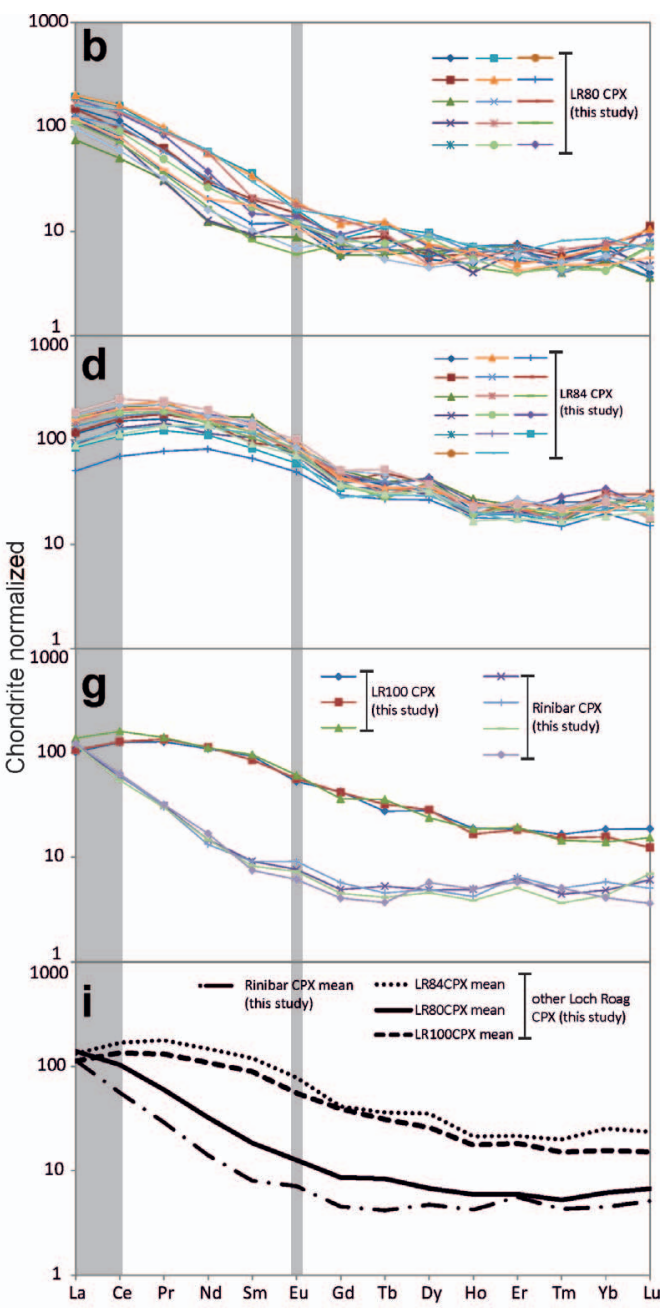

FIG. 12. Primitive mantle-normalized multi-element diagrams and chondrite-normalized REE diagrams for clinopyroxene (determined by LA-ICP-MS) from Loch Roag and Rinibar spinel lherzolites. $(a)$ and $(b)$ for sample LR80 ('fresh' spinel lherzolite). (c) and (d) for LR84 (green clinopyroxenite xenolith). (e) and $(g)$ for LR100 (green clinopyroxenite xenolith). $(f)$ and $(g)$ for Rinibar xenolith 'R2' (partially serpentinized spinel lherzolite). Average (mean) clinopyroxene compositions per sample are displayed in $(h)$ and $(i)$. Primitive mantle (pyrolite) and chondrite normalizing values from McDonough and Sun (1995). 
identified in LR84 and LR100 plot in the same cluster as these two metasomatic compositions ('Streap type-1' and 'Rinibar type-2' from Bonadiman et al., 2008 as a function of $(\mathrm{Gd} /$ $\left.\mathrm{Lu})_{\mathrm{N}}\right)$. By contrast, according to $(\mathrm{La} / \mathrm{Sm})_{\mathrm{N}}$ (Fig. 13a), LR80 and our Rinibar sample (R2) plot entirely separately from the 'metasomatic' pyroxene compositions and must reflect a different origin.

We have further experimented with ways by which to characterize clinopyroxene composition in the mantle - for example according to $(\mathrm{Zr} / \mathrm{Hf})_{\mathrm{N}}$ and $(\mathrm{Nb} / \mathrm{Ta})_{\mathrm{N}}$ (Fig. 13c). Metasomatic clinopyroxenes have a low $(\mathrm{Zr} / \mathrm{Hf})_{\mathrm{N}}$ typically $\leqslant 1.5$, while 'primary' clinopyroxene has substantially greater $(\mathrm{Zr} / \mathrm{Hf})_{\mathrm{N}}$ ranging from $>1.5$ to 50 . Good characterization of clinopyroxene compositions ('primary' vs. 'metasomatic') can also be based on $\mathrm{Ga}, \mathrm{Y}, \mathrm{MgO}, \mathrm{Cr}$ and $\mathrm{Ni}$ contents (Fig. 12d-f). In detail, 'primary' clinopyroxenes have a wide range of $\mathrm{Ni}$ contents (200 to $>1000 \mathrm{ppm}$ ) but limited variation in Cr. In contrast metasomatic clinopyroxenes have elevated and wide-ranging $\mathrm{Cr}$ concentrations $(\sim 1.4$ to 3 wt.\% $\mathrm{Cr})$.

\section{Discussion}

In this study, we have compared the compositions of Scottish spinel lherzolites with those from elsewhere in the North Atlantic Craton (in western and eastern Greenland). On a terrane-scale in northwest Scotland, xenoliths appear to fall into two groups - one which overlaps Greenlandic cratonic NAC xenolith major-element abundances (e.g. Loch Roag and Rinibar) and one which does not and is more akin to 'primitive upper mantle' (e.g. Streap Com'laidh). The question arises: does this discrepancy reflect terrane-scale mantle heterogeneity between the Hebridean and Northern Highland terranes, or do they form a continuous range in a heterogeneous lithospheric mantle? Are these simply the consequence of limited samples from heterogeneous mantle lithosphere? The $\mathrm{Cu}$ abundances of the Scottish xenoliths are unusually elevated above concentrations elsewhere in the NAC, or globally for cratonic SCLM - are these 'primary' abundances or have these been recently re-enriched? Similarly, are the critical-metal (e.g. REE) concentrations of the Scottish SCLM a 'primary' or 'metasomatic' feature? And what are the overall mineralogical controls on REE and trace-element abundance in the SCLM?

\section{Terrane-scale variation in the northwest Scottish lithospheric mantle}

As outlined previously, the lithospheric terranes of Scotland were largely amalgamated and assembled into their present positions during the Caledonian Orogeny. At the surface, Lewisian and/or 'Lewisianoid' exposures suggest that the British portion of the NAC (at least at a crustal level) includes the land masses to the north and northwest of the GGF.

All three suites of xenoliths from the Scottish margin of the NAC (i.e. north of the GGF) are notably less refractory (lower $\mathrm{MgO}$, higher $\mathrm{Al}_{2} \mathrm{O}_{3}$ and generally higher $\mathrm{FeO}^{\mathrm{T}}$ ) than their Greenlandic counterparts (Fig. $8 a-b$ ). While the majorelement compositions of these Scottish xenoliths is similar to that of ultramafic cumulate rocks from the Archaean Tartoq supracrustal belt of SW Greenland (e.g. Szilas et al., 2014) we see no textural or mineralogical evidence to suggest that the spinel peridotite xenoliths of Loch Roag, Rinibar and Streap Com'laidh are anything other than upper mantle lithologies (see Upton et al., 2011 and references therein and c.f., Downes et al., 2007). This suggests that the Scottish margin has either been re-fertilized separately from the wider NAC, or was not as extensively depleted. In detail however, there are differences in xenolith composition between the three Scottish xenolith localities - e.g. between the southwest and northeast portions of the Northern Highland terrane. While the Rinibar xenoliths are more serpentinized than those from Streap Com'laidh, their anhydrous major-element compositions overlap those from elsewhere in the NAC and other cratons (Fig. $8 a-b$ and $d-h$ ). In contrast the fresher Streap Com'laidh xenoliths show a very narrow range in major-element abundances, more similar to the 'primitive upper mantle' of McDonough and Sun (1995).

FIG. 13 (facing page). Binary plots for clinopyroxene from Loch Roag and Rinibar spinel lherzolites (this study). Results for Streap Com'laidh and Rinibar lherzolites from Bonadiman et al. (2008) are shown also for comparison. The $\mathrm{Eu} / \mathrm{Eu}^{*}$ anomaly is calculated as $\mathrm{Eu}_{\mathrm{N}} /\left(\left(\mathrm{Sm}_{\mathrm{N}}+\mathrm{Gd}_{\mathrm{N}}\right) \times 0.5\right)$ where ' $\mathrm{N}$ ' denoted chondrite normalization. 
TRACE ELEMENTS IN THE NAC LITHOSPHERIC MANTLE
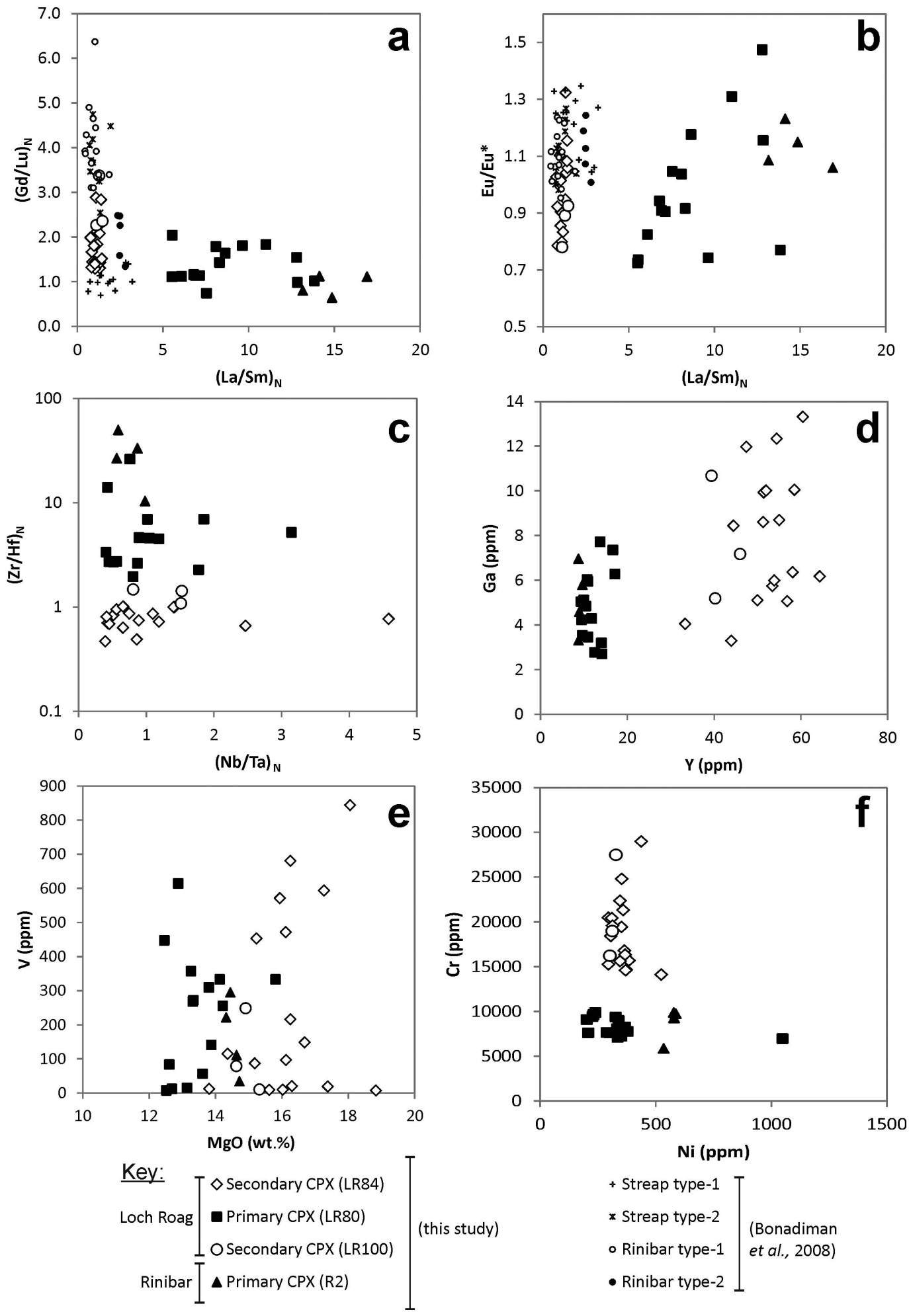
Both Northern Highland terrane xenolith suites were entrained into Permo-Carboniferous dykes, and thus they were removed and isolated from the SCLM well before the Palaeogene impingement of the Icelandic plume. Despite the major elements of Streap Com'laidh xenoliths recording a comparatively undepleted mantle composition, in agreement with other isotopic evidence (e.g. ${ }^{3} \mathrm{He} /{ }^{4} \mathrm{He}$ of fluid inclusions in olivine, Kirkstein et al., 2004; and whole-rock and clinopyroxene Sr- and Ndisotopes, Menzies and Halliday, 1988; Downes et al., 2001, 2007; Bonadiman et al., 2008), Streap Com'laidh xenoliths do not display any of the characteristic positive or negative anomalies seen in samples from Loch Roag or Rinibar (e.g. for $\mathrm{Nb}, \mathrm{Ta}, \mathrm{Zr}, \mathrm{Hf}, \mathrm{Ti}$ and LREE). Similarly, trace elements such as Co (Fig. 9c) occur at lower concentrations, with correspondingly higher V, than in the other Scottish or cratonic xenoliths globally. Thus in many ways, both geochemically and isotopically, the Streap Com'laidh spinel lherzolites resemble shallow upper mantle compositions underlying MORB, high-temperature offcraton settings, or truly primitive upper mantle. Although the xenoliths were derived from the lithospheric mantle underlying Streap Com'laidh, the very process of xenolith entrainment in the magmas of the host dyke is likely to have introduced a natural sampling bias, such that not all SCLM lithologies will have been entrained into the dyke or preserved at the current level of exposure. As such Streap Com'laidh spinel lherzolites may not in fact be representative of the truly cratonized margin of the NAC at all, and could instead constitute fragment(s) of 'exotic' mantle (possibly part of the Iapetus slab subducted during the Caledonian orogeny). This is corroborated by Bonadiman et al. (2008) who highlighted that the fine crystal sizes prevalent in Streap Com'laidh peridotite xenoliths do not concur with either simple 'pure' Archaean to Phanerozoic cratonic, or Phanerozoic off-cratonic environments. Rheological and thermal evidence may suggest that the Streap Com'laidh xenoliths crystallized in a high-stress environment, which allowed for efficient dynamic recrystallization and perturbing the Ostwald ripening long-term hightemperature low-stress regime dominant in Archaean subcratonic mantle (Silver et al., 1999; Pearson et al., 2003).

By contrast, the spinel lherzolites of Rinibar and Loch Roag are geochemically similar, despite being entrained in host dykes separated in age by more than 200 Myr. For example, the whole-rock major-element compositions of both suites overlap, and the REE abundances in both Rinibar samples and LR80 (fresh spinel lherzolite xenolith 'core') are very similar. Both Loch Roag and Rinibar lherzolites display negative wholerock $\mathrm{Nb}, \mathrm{Ta}$ and $\mathrm{Ti}$ anomalies (Fig. 11a). Other trace elements however, reveal subtle discrepancies; e.g. $\mathrm{Ba}$ and $\mathrm{Sr}$ (and $\mathrm{P}$ in one sample) are enriched in Rinibar samples in comparison to those from Loch Roag. Given the relative proximity of a suite of late-Caledonian $(\sim 430-420 \mathrm{Ma})$ high $\mathrm{Ba}-\mathrm{Sr}$ mixed dioritegranitoid, syenite and pyroxenite-syenite intrusions in northern Scotland (for example at Loch Borralan, Loch Loyal, Helmsdale, Rogart and Ach' Uaine) and especially accounting for Caledonian westward motion along the MTZ, it is plausible that the SCLM of this northeast region was affected by the transient large-ion lithophile element rich melts or fluids of that time. This would suggest that a Caledonian subductionrelated signature has (in part) been recorded or preserved in this region of the SCLM, for example representing part of the Caledonian Parental Magma Array (Fowler et al., 2008).

The spinel lherzolites from Loch Roag (e.g. samples LR80, LR81, LR90, LR289 and LR101335) have more steeply fractionated chondrite-normalized $R E E$ patterns, with notable negative $\mathrm{Eu}$ anomalies in comparison to the green clinopyroxenite samples of LR84 and LR100. LR80 has the smallest negative Eu anomaly in comparison to the other spinel lherzolites, and given that the bulk powdering of LR80 involved the removal of the oxidized and barite-bearing outer 'altered' rim of this xenolith, it might suggest that the negative Eu anomaly is largely controlled by this 'altered' rim material. Otherwise the relative depletion in Eu on Fig. 10a for Loch Roag lherzolites suggests that at some point during the history of the xenoliths, plagioclase feldspar was fractionating (melted out) of a pre-spinel lherzolite protolith, or that metasomatism from a fluid in equilibrium with plagioclase had occurred. Both of these scenarios would be highly unusual in mantle lithologies.

For the green clinopyroxenites (LR84 and LR100), $\mathrm{Zr}$ and $\mathrm{Hf}$ concentrations are an order of magnitude higher than other Loch Roag wholerock samples; a result of elevated $\mathrm{Zr}$ and $\mathrm{Hf}$ contents of their component clinopyroxene (e.g. Fig. 12). However beyond this, no systematic differences in whole-rock geochemistry can be established between the lherzolites and green 
clinopyroxenites except for slightly higher $\mathrm{K}_{2} \mathrm{O}$ and $\mathrm{TiO}_{2}$ concentrations in the spinel lherzolites. Therefore, if the green clinopyroxenite samples truly represent modally metasomatized SCLM peridotites, they have largely retained the majorand trace-element bulk compositions of the spinel lherzolites (including the 'fresh' xenolith core composition of LR80).

\section{Rare-earth elements of the sub-Lewisian lithosphere}

The Loch Roag and Rinibar xenoliths are unusually rich in LREE. The Rinibar spinel lherzolites and sample LR80 from Loch Roag (which sampled only the 'fresh' grey peridotite interior of the xenolith) have $L R E E$ abundances elevated well above chondrite (Fig. 10a) but these are not as enriched as other Loch Roag xenoliths. Samples LR90, LR81, LR101335 and LR289 are also spinel lherzolites, but whole-rock powder included green-brown xenolith rims which contain traces of barite, $\mathrm{Fe}^{3+}$ oxides and serpentine. This is reflected in their higher LOI values (>1 wt.\%, Table 2$)$. These xenoliths with altered rims also have extremely enriched $L R E E$ patterns, well in excess of $100 \times$ chondrite (Fig. 10a), with negative $\mathrm{Eu}$ anomalies. This clearly indicates that the haloes are not simply surface weathering artefacts. The REE pattern of the Loch Roag monchiquite dyke lacks a Eu anomaly, so a simple link to the host rock seems unlikely. Currently we do not know whether the enhanced $L R E E$ is caused by the same process as the alteration/oxidation, or whether the association is incidental, and instead reflects an increased susceptibility to such alteration in the LREEenriched peridotites.

The effect of accessory mineralogy on $R E E$ whole-rock geochemistry can be significant and is easily overlooked. In one Loch Roag xenolith (LR84) a chlorite- and serpentine-filled veinlet has been overprinted by bastnäsite (Ce carbonate) - Fig. $6 e-f$. Clearly $\mathrm{Ce}$ (and La) are major constituents of this mineral, and thus only trace amounts of bastnäsite would have a significant impact on the whole-rock geochemistry of the powdered rock. Similar bastnäsite-filled veins have not been found in any other xenoliths in this study. Nonetheless this highlights the importance of detailed petrography in mantle xenolith studies.

Under $\mathrm{H}_{2} \mathrm{O}$-rich conditions, (e.g. in mantle wedges above subduction zones) chlorite can be stable to temperatures just above the $\mathrm{H}_{2} \mathrm{O}$ saturated solidus between 2 and $3.6 \mathrm{GPa}$ (Till et al., 2012; Grove et al., 2006). Chlorite is not uncommon in kimberlites and associated mantle xenoliths. Tompkins et al. (1984) reviews occurrences, and describes chlorite from kimberlites in Sierra Leone. They propose that chlorite is formed by relatively low-temperature alteration of phlogopite by a late $\mathrm{H}_{2} \mathrm{O}$ and $\mathrm{CO}_{2}$-rich fluid exsolved from kimberlites. Upton et al. (2009) describe chloritic rims around ocelli from a range of Scottish monchiquite/nephelinitic dykes, and ascribe these to separation of a carbonate-rich melt/fluid. A similar effect seems a very plausible process within Loch Roag dyke, and the occurrence of LREE-rich bastnäsite would be consistent with a carbonatitic melt/fluid. Such $L R E E$-rich fluids may also explain the 'altered' outer zones of xenoliths with high LREE abundances, although the serpentine-oxide-barite assemblage might suggest a more oxidized, and perhaps less $\mathrm{CO}_{2}$-rich (perhaps lower temperature) fluid than that responsible for the chlorite-bastnäsite vein.

The Loch Roag dyke displays clear evidence for at least limited post-magmatic fluid flow in the form of zeolites on some joint planes and lining vesicles (Faithfull et al., 2012). The REE can be mobile in zeolite-facies fluids: ancylite-(Ce) and kainosite-(Y) are found in zeolite-rich veins at Strontian for example (Green and McCallum, 2005). All of these possible origins would imply that the LREE-enriched crusts and veins are synor post-emplacement features, but such processes make it hard to explain the negative Eu anomalies in the $L R E E$-rich zones of the mantle peridotite xenoliths.

\section{'Primary' vs. 'metasomatic' signatures in the SCLM}

Whole-rock geochemistry involves the homogenization of a xenolith, thus incorporating a variety of silicate, oxide, sulfide and other accessory minerals for a combined analytical result. These data give a composite of the sample mineralogy and must be put into context at an individual mineralogical scale. Olivine and orthopyroxene will only incorporate very low abundances of incompatible lithophile trace elements, while controlling a large proportion of the $\mathrm{MgO}, \mathrm{FeO}$, $\mathrm{Al}_{2} \mathrm{O}_{3}, \mathrm{Ni}$ and $\mathrm{Cr}$ whole-rock budget. Orthopyroxene may also regulate a significant component of whole-rock trace-element 
geochemistry, despite its low overall abundances. Clinopyroxene will incorporate a variety of incompatible lithophile trace elements in significant quantities in addition to $\mathrm{CaO}, \mathrm{Na}_{2} \mathrm{O}$ and $\mathrm{Cr}_{2} \mathrm{O}_{3}$. In terms of whole-rock geochemistry, an increase in clinopyroxene abundance correlates with an elevation in Sc and other trace elements (e.g. Fig. 9a) and the composition of SCLM clinopyroxene may be sensitive to magmatic and/ or metasomatic events.

Clinopyroxenes from Rinibar and Streap Com'laidh reported in Bonadiman et al. (2008) are spongy in texture, with inclusions of other clinopyroxenes, olivine and spinel. From the trace-element composition of these 'spongy' clinopyroxenes, we support the interpretation of Bonadiman et al. (2008) that they are secondary and probably metasomatic in origin. Similar 'spongy' clinopyroxene textures with olivine and chromite inclusions occur in Loch Roag green clinopyroxenite xenoliths (LR84 and LR100). The LA-ICP-MS trace-element results correspond closely with those from Bonadiman et al. (2008). In particular, chondrite-normalized REE patterns of their metasomatic pyroxenes display characteristic convex LREE patterns with $\mathrm{Ce}_{\mathrm{N}}$ enriched over $\mathrm{La}_{\mathrm{N}}$ matching the LR84 and LR100 clinopyroxenes (e.g. Fig. $12 d$ and g). Using $(\mathrm{Gd} / \mathrm{Lu})_{\mathrm{N}}$ as a proxy for kimberlite $v s$. carbonatite metasomatic clinopyroxene (the former having high $(\mathrm{Gd} / \mathrm{Lu})_{\mathrm{N}}>2.5$, and the latter with low $(\mathrm{Gd} / \mathrm{Lu})_{\mathrm{N}}<2.5$ based on Bonadiman et al., 2008), we suggest that the 'spongy' clinopyroxenes of Loch Roag formed during a carbonatite-related metasomatic event and supports isotopic evidence from Long et al. (1991) which cited timeintegrated Nd-isotopes as recording carbonatiterelated metasomatism at $\sim 2.4 \mathrm{Ga}$. Other metasomatic influxes are indicated across the Hebridean and Northern Highland terranes. For example, Sr-Nd isotopic compositions from metasomatic clinopyroxenes indicate an overprinting event for Rinibar at $550 \pm 50 \mathrm{Ma}$ (Bonadiman et al., 2008) - prior to both Iapetus oceanic subduction and any possible melt/fluid mobilization associated with the initiation of the Great Glen Fault.

By contrast, we suggest that the comparatively homogeneous clinopyroxenes in spinel lherzolites from Loch Roag (e.g. LR80) and Rinibar (see Fig. 12) are of primary origin. Texturally, these clinopyroxenes are part of a protogranular to subequigranular suite of peridotites, and do not contain granular mineral inclusions of any type.
Their trace-element compositions are distinct from the metasomatic clinopyroxene compositions discussed previously. For instance, $(\mathrm{La} / \mathrm{Sm})_{\mathrm{N}}$ in 'primary' clinopyroxene is somewhat counterintuitively elevated by more than 5 to 10 times above that of the metasomatic compositions (Fig. 13a). Primary clinopyroxenes also have comparatively low $\mathrm{Y}$ and $\mathrm{Cr}$ concentrations (Fig. $13 d$ and $f$ ) and substantial enrichment in $\mathrm{U}$ and Th (Fig. $12 a$ and f). Hence, these 'primary' pyroxenes represent the original cratonic clinopyroxene prevalent at the Scottish margin of the NAC, although some aspects of their geochemistry may since have been modified cryptically, as discussed later.

The Hf-Zr systematics of clinopyroxenes in the Scottish peridotite xenoliths are highly variable (Figs 12 and 13c). In our study, 'metasomatic' clinopyroxenes from LR84 and LR100 have Zr and $\mathrm{Hf}$ concentrations elevated to more than 10 times that of the primitive mantle and $(\mathrm{Zr} / \mathrm{Hf})_{\mathrm{N}}$ ratios $\leqslant 1.5$. Crucially these clinopyroxenes also have very elevated $\mathrm{Cr}$ contents, a feature well documented in other 'metasomatic' mantle clinopyroxenes across the world (e.g. Lloyd et al., 1991; Gysi et al., 2011). By contrast, 'primary' Rinibar (R2) and Loch Roag (LR80) clinopyroxenes have severely decoupled $\mathrm{Zr}$ and $\mathrm{Hf}$, with $(\mathrm{Zr} / \mathrm{Hf})_{\mathrm{N}}$ ranging from $2-50$ (Fig. 13), as a result of enrichment in $\mathrm{Zr}$, with $\mathrm{Hf}_{\mathrm{N}}$ typically $\sim 1$ (Fig. 12). The 'metasomatic' pyroxenes from Rinibar (Bonadiman et al., 2008) have similarly decoupled $\mathrm{Zr}$ and $\mathrm{Hf}$ in carbonatite-associated phases, as in our 'primary' pyroxenes, but kimberlite-associated metasomatic pyroxenes have elevated $\mathrm{Hf}_{\mathrm{N}}$ more akin to Loch Roag metasomatic types. Streap Com'laidh clinopyroxenes from Bonadiman et al. (2008) have similar $(\mathrm{Zr} / \mathrm{Hf})_{\mathrm{N}}$ ratios as in 'primary' Loch Roag (LR80), but the characteristic convex LREE pattern of modal metasomatic phases, and substantially lower Th and U concentrations.

Downes et al. (2015) recently investigated the $\mathrm{Zr}$ and $\mathrm{Hf}$ composition of clinopyroxenes from French and Polish spinel peridotite mantle xenoliths. Initial extensive partial melting of primitive mantle removed both $\mathrm{Zr}$ and $\mathrm{Hf}$, but these extreme depletions are rarely identified in mantle xenoliths globally. Modelling of $\mathrm{Hf}$ depletion in clinopyroxenes from the French Massif Central has suggested this results from up to $30 \%$ partial melting in the spinel peridotite stability field (Wittig et al., 2006). In their study, Downes et al. (2015) identified metasomatism in 
clinopyroxenes by the substantial elevation of either $\mathrm{Zr}$ abundances only, or both $\mathrm{Zr}$ and $\mathrm{Hf}$, depending on the metasomatizing agent (i.e. a subduction-related fluid, alkaline silicate melt, or carbonatite).

Taking into account the study of Downes et al. (2015) and the other distinct trace-element characteristics of each xenolith-clinopyroxene population (e.g. Th, U, Nb, Ta and LREE patterns), we suggest that the spongy metasomatic clinopyroxenes of Loch Roag (e.g. LR84, LR100) demonstrate the modal metasomatic record of lithospheric mantle. Both $\mathrm{Zr}_{\mathrm{N}}$ and $\mathrm{Hf}_{\mathrm{N}}$ are elevated in secondary pyroxenes to $>10 \times$ PUM whereas 'primary' clinopyroxenes may record secondary cryptic metasomatism, revealed by a substantial elevation in $\mathrm{Zr}_{\mathrm{N}}$ over $\mathrm{Hf}_{\mathrm{N}}$ (e.g. Rinibar, sample R2) with $\mathrm{Hf}_{\mathrm{N}}$ remaining at $\leqslant 1.5$ primitive mantle concentrations. Based on the similarity of $L R E E, \mathrm{U}$ and $\mathrm{Th}$ abundances to 'primary' Rinibar compositions, this explanation may therefore be extended to 'primary' Loch Roag clinopyroxenes (i.e. LR80). Thus 'primary' clinopyroxene compositions may largely record initial subcratonic lithospheric geochemistry, however certain high field-strength elements, widely regarded as 'immobile' (e.g. Pearce, 1996), may record significant cryptic geochemical evidence of subsequent modification. Importantly, the absence of a true depletion in $\mathrm{Hf}_{\mathrm{N}}$ in 'primary' clinopyroxenes of both suites, suggests that no severe partial melting event(s) are recorded in the spinel lherzolites from the Scottish portion of the NAC SCLM.

The Scottish xenoliths enable us to understand the SCLM record. Xenoliths in Loch Roag are entrained in an Eocene-aged dyke, emplaced at the end of the magmatism recorded in the UK during the Palaeogene impingement of the Icelandic mantle plume under western Scotland. By contrast the Rinibar xenoliths were entrained in a Permo-Carboniferous dyke and predate the effects of the Icelandic plume. Given the timescale between cratonization of the NAC and the Permo-Carboniferous entrainment (and thus isolation) of the Rinibar xenoliths (in the order of billions of years) $v s$. the timescale between isolation of the Rinibar and Loch Roag xenoliths ( $\sim 250 \mathrm{Myr})$, it seems sensible to suggest that they document a prolonged Archaean and Proterozoic history at the margin of the NAC SCLM, rather than subsequent Phanerozoic events. Therefore similarities in clinopyroxene (and other mineralogical) compositions are unlikely to be coin- cidental. Loch Roag spinel lherzolites probably record ancient lithospheric shallow mantle compositions (although not notably depleted relative to PUM - e.g. $\mathrm{Al}_{2} \mathrm{O}_{3}$ ) and have not been substantially reset, destroyed or recrystallized during the Palaeogene plume event. A new study investigating the common similarities between Loch Roag spinel lherzolite traceelement compositions and that of the Scourie Dyke Swarm (erupted during an extensional tectonic event in the Palaeoproterozoic) highlighted that, despite their Eocene entrainment age, the lithospheric mantle as represented by the Loch Roag xenoliths retained bulk geochemical features that are important to the geochemistry of the 2.4 Ga Scourie Dyke magmas (Hughes et al., 2014) including their apparent enrichment in $\mathrm{Cu}$. In short, upper mantle of similar/the same composition to that of xenolith LR80 was partially melted during the Palaeoproterozoic, and fed magmas (predominantly sourced in the lithospheric mantle) which ultimately formed the Scourie Dyke Swarm (Hughes et al., 2014). Combined, these are essential observations for further investigations into the cratonic, or marginal cratonic, lithospheric mantle's geochemistry and metal abundances, and for understanding whether these xenoliths record a 'primary' metal enrichment as part of the ancient SCLM keel.

\section{Conclusions}

(1) According to major-element abundances, spinel lherzolite xenoliths from the Scottish margin of the NAC show no evidence of severe depletion, unlike xenoliths from the Greenlandic NAC.

(2) Cerium carbonate (bastnäsite) has been discovered in a Loch Roag clinopyroxene-rich mantle peridotite, however the provenance of this mineral is likely to be a secondary lowertemperature (hydrothermal?) event and not associated with the lithospheric mantle itself. Overall we highlight the importance of petrography, particularly for accessory minerals, before whole-rock geochemical or isotopic analyses, in order to put the main controls on metal abundance into context.

(3) Copper abundances in the spinel lherzolites of Loch Roag are extremely enriched and are elevated above cratonic or Archaean-Proterozoic mantle peridotite compositions worldwide, currently available in the published literature. Specifically this is an enrichment in sulfide and 
$\mathrm{Cu}$ associated with a melt/fluid event although the timing is poorly constrained (pre-Phanerozoic).

(4) Clinopyroxene compositions from Rinibar and Loch Roag have characteristic features including depletions in $\mathrm{Nb}, \mathrm{Ta}$ and $\mathrm{Ti}$, and clinopyroxenes formed from metasomatic events can be identified by enriched LREE such that Ce is enriched over $\mathrm{La}$ (on chondrite-normalized diagrams) and elevated $\mathrm{Cr}$ content. Cryptic 'refertilization' or metasomatism of 'primary' clinopyroxenes can be identified by decoupling of $\mathrm{Zr}$ from $\mathrm{Hf}$, such that $\mathrm{Zr}$ becomes enriched. The lack of true Hf depletion in these 'primary' clinopyroxenes suggests that the xenoliths have not undergone severe partial melting.

(5) We use clinopyroxene compositions, in context with accessory mineral occurrences, to suggest that the Scottish NAC margin has not undergone recent Phanerozoic melting or refertilization, despite the proximity of the Icelandic mantle plume during the Palaeogene opening of the Atlantic. Further, similarities in trace-element systematics between the Loch Roag spinel lherzolites and Palaeoproterozoic Scourie Dyke Swarm (Hughes et al., 2014) would suggest that these xenoliths represent the composition of shallow mantle that is at least Palaeoproterozoic in age. As such, we suggest that the whole-rock $R E E$ and other trace-element abundances in these xenoliths (e.g. $\mathrm{Cu}$ ) represent either the original cratonic composition or ancient metasomatized Archaean-Palaeoproterozoic compositions, and that the green clinopyroxenites from Loch Roag may represent a different, more recent volatilerich or metasomatic event.

\section{Acknowledgements}

Much of the material (xenolith and dyke) used throughout this study is from B.G.J. Upton's personal collection, now held at the British Geological Survey (BGS), Murchison House, Edinburgh. The BGS, particularly Michael Togher, is thanked for the curation, access and use of these samples. New samples from Streap Com'laidh were collected by J.W. Faithfull, and are curated at the Hunterian Museum, University of Glasgow. Anthony Oldroyd is thanked for preparation of polished thin sections and Peter Fisher for assistance and guidance at Cardiff University's SEM facility. This manuscript benefitted greatly from discussions with Andrew Fagan and Nicholas Arndt. Reviews from Sebastian Tappe, Kristoffer Szilas and Fanus
Viljoen helped to improve the paper. H.S.R. Hughes was funded by the Natural Environment Research Council (NERC) studentship NE/J50029X/1

\section{References}

Arndt, N.T. (2013) The lithospheric mantle plays no active role in the formation of orthomagmatic ore deposits. Economic Geology, 108, 1953-1970.

Barton, P.J. (1992) LISPB revisited: a new look under the Caledonides of northern Britain. Geophysical Journal International, 110, 371-391.

Baxter, A.N. and Mitchell, J.G. (1984) Camptonitemonchiquite dyke swarms of northern Scotland; age relationships and their implications. Scottish Journal of Geology, 20, 297-308.

Bernstein, S., Kelemen, P.B. and Brooks, C.K. (1998) Depleted spinel harzburgite xenoliths in Tertiary dykes from East Greenland: Restites from high degree melting. Earth and Planetary Science Letters, 154, 221-235.

Bernstein, S., Hanghøj, K., Kelemen, P.B. and Brooks, K. (2006) Ultra-depleted shallow cratonic mantle beneath West Greenland: dunitic xenoliths from Ubekendt Ejland. Contributions to Mineralogy and Petrology, 152, 335-347.

Bernstein, S., Kelemen, P.B. and Hanghøj, K. (2007) Consistent olivine $\mathrm{Mg \#}$ in cratonic mantle reflects Archean mantle melting to the exhaustion of orthopyroxene. Geology, 35, 459.

Bernstein, S., Szilas, K. and Kelemen, P.B. (2013) Highly depleted cratonic mantle in West Greenland extending into diamond stability field in the Proterozoic. Lithos, 168-169, 160-172.

Bizzarro, M. and Stevenson, R.K. (2003) Major element composition of the lithospheric mantle under the North Atlantic craton: Evidence from peridotite xenoliths of the Sarfartoq area, southwestern Greenland. Contributions to Mineralogy and Petrology, 146, 223-240.

Bonadiman, C., Coltorti, M., Duggen, S., Paludetti, L., Siena, F., Thirlwall, M.F. and Upton, B.G.J. (2008) Palaeozoic subduction-related and kimberlite or carbonatite metasomatism in the Scottish lithospheric mantle. Pp. 303-333 in: Metasomatism in Oceanic and Continental Lithospheric Mantle (M. Coltorti and M. Gregoire, editors). The Geological Society, London.

Bridgwater, D., Watson, J. and Windley, B.F. (1973) The Archaean Craton of the North Atlantic Region. Philosophical Transactions of the Royal Society A: Mathematical, Physical and Engineering Sciences, 273, 493-512.

Buchan, K.L., Mertanen, S., Park, R.G., Pesonen, L.J., Elming, S.-A., Abrahamsen, N. and Bylund, G. 
(2000) Comparing the drift of Laurentia and Baltica in the Proterozoic: the importance of key palaeomagnetic poles. Tectonophysics, 319, 167-198.

Davies, J.H.F.L. and Heaman, L.M. (2014) New U-Pb baddeleyite and zircon ages for the Scourie dyke swarm: A long-lived large igneous province with implications for the Paleoproterozoic evolution of NW Scotland. Precambrian Research, 249, $180-198$.

Downes, H. (2007) Origin and significance of spinel and garnet pyroxenites in the shallow lithospheric mantle: Ultramafic massifs in orogenic belts in Western Europe and NW Africa. Lithos, 99, 1-24.

Downes, H., Upton, B.G.J., Handryde, E.A.J. and Thirlwall, M.F. (2001) Geochemistry of mafic and ultramafic xenoliths from Fidra (Southern Uplands, Scotland): implications for lithospheric processes in Permo-Carboniferous times. Lithos, 58, 105-124.

Downes, H., Upton, B.G.J., Connolly, J., Beard, A.D. and Bodinier, J.-L. (2007) Petrology and geochemistry of a cumulate xenolith suite from Bute: evidence for late Palaeozoic crudtal uderplating beneath SW Scotland. Journal of the Geological Society, 164, 1-15.

Downes, H., de Vries, C. and Wittig, N. (2015) Hf-Zr anomalies in clinopyroxene from mantle xenoliths from France and Poland: implications for $\mathrm{Lu}-\mathrm{Hf}$ dating of spinel peridotite lithospheric mantle. International Journal of Earth Sciences, 104, 89-102

Faithfull, J.W., Timmerman, M.J., Upton, B.G.J. and Rumsey, M.S. (2012) Mid-Eocene renewal of magmatism in NW Scotland: the Loch Roag Dyke, Outer Hebrides. Journal of the Geological Society, 169, 115-118.

Fowler, M.B., Kocks, H., Darbyshire, D.P.F. and Dreenwood, P.B. (2008) Petrogenesis of high Ba-Sr plutons from the Northern Highlands Terrane of the British Caledonian Province. Lithos, 105, 129-148.

Goodenough, K.M., Macdonald, J.M., Johnson, T.E., Hughes, H.S.R., Shaw, R.A. and Millar, I. (2014) Tectoic history and mineralisation in the North Atlantic Craton: A view from Scotland. North Atlantic Craton Conference, 2014. University of St Andrews, UK.

Goodenough, K.M., Millar, I., Strachan, R.A., Krabbendam, M. and Evans, J.A. (2011) Timing of regional deformation and development of the Moine Thrust Zone in the Scottish Caledonides: constraints from the U-Pb geochronology of alkaline intrusions. Journal of the Geological Society, London, 168, 99-114.

Green, D.I. and McCallum, D. (2005) Kainosite-(Y) from the Strontian Mines, Highland Region, Scotland. UK Journal of Mines and Minerals, 26, $23-26$.
Griffin, W.L. and O'Reilly, S.Y. (1987) Is the continental Moho the crust-mantle boundary? Geology, 15, 241.

Grove, T.L., Chatterjee N., Parman S.W. and Medard E. (2006) The influence of $\mathrm{H}_{2} \mathrm{O}$ on mantle wedge melting. Earth and Planetary Science Letters, 249(1-2), 74-89.

Groves, D.I. and Bierlein, F.P. (2007) Geodynamic settings of mineral deposit systems. Journal of the Geological Society, London, 164, 19-30.

Groves, D.I., Ho, S.E., Rock, N.M.S., Barley, M.E. and Muggeridge, M.T. (1987) Archean cratons, diamond and platinum: Evidence for coupled long-lived crustmantle systems. Geology, 15, 801-805.

Gysi, A.P., Jagoutz, O., Schmidt, M.W. and Targuisti, K. (2011) Petrogenesis of pyroxenites and melt infiltrations in the ultramafic complex of Beni Bousera, Northern Morocco. Journal of Petrology, 52, 1679-1735.

Hanghoj, K., Kelemen, P.B., Bernstein, S., Blusztajn, J. and Frei, R. (2001) Osmium isotopes in the Wiedemann Fjord mantle xenoliths: A unique record of cratonic mantle formation by melt depletion in the Archaean. Geochemistry Geophysics Geosystems, 2, $1-14$.

Hughes, H.S.R., McDonald, I., Goodenough, K.M., Ciborowski, T.J.R., Kerr, A.C., Davies, J.H.F.L. and Selby, D. (2014) Enriched lithospheric mantle keel below the Scottish margin of the North Atlantic Craton: Evidence from the Palaeoproterozoic Scourie Dyke Swarm and mantle xenoliths. Precambrian Research, 250, 97-126.

Hunter, R.H. and Upton, B.G.J. (1987) The British Isles - a Palaeozoic mantle sample. Pp. 107-118 in: Mantle xenoliths. (P.H. Nixon, editor). John Wiley, Chichester, UK.

Hutchison, M. and Frei, D. (2009) Kimberlite and related rocks from Garnet Lake, West Greenland, including their mantle constituents, diamond occurrence, age and provenance. Lithos, 112, 318-333.

Kinny, P.D., Strachan, R.A., Kocks, H. and Friend, C.R.L. (2003) U-Pb geochronology of late Neoproterozoic augen granites in the Moine supergroup, NW Scotland: dating of rift-related, felsic magmatism during supercontinent break-up? Journal of the Geological Society, London, 160, 925-934.

Kinny, P.D., Friend, C.R.L. and Love, G.J. (2005) Proposal for a terrane-based nomenclature for the Lewisian Complex of NW Scotland. Journal of the Geological Society, London, 162, 175-186.

Kirstein, L.A., Dunai, T.J., Davies, G.R., Upton, B.G.J. and Nikogosian, I.K. (2004) Helium isotope signature of lithospheric mantle xenoliths from the Permo-Carboniferous magmatic province in Scotland - no evidence for a lower-mantle plume. Pp. 243-258 in: Permo-Carboniferous Magmatism 
and Rifting in Europe (M. Wilson, E.-R. Neumann, G.R. Davies, M.J. Timmerman, M. Heeremans and B.T. Larsen, editors). Geological Society Special Publications, 223. The Geological Society, London.

Kirstein, L.A., Davies, G.R. and Heeremans, M. (2006) The petrogenesis of Carboniferous-Permian dyke and sill intrusions across northern Europe. Contributions to Mineralogy and Petrology, 152, 721-742.

Kneller, B.C. (1991) A foreland basin on the southern margin of Iapetus. Journal of the Geological Society, London, 148, 207-210.

Kolb, J., Dziggel, A. and Schlatter, D.M. (2013) Gold occurrences of the Archean North Atlantic craton, southwestern Greenland: A comprehensive genetic model. Ore Geology Reviews, 54, 29-58.

Kumar, P., Kind, R., Hanka, W., Wylegalla, K., Reigber, Ch., Yuan, X., Woelbern, I., Schwintzer, P., Fleming, K., Dahl-Jensen, T., Larsen, T.B., Schweitzer, J., Priestley, K., Gudmundsson, O. and Wolf, D. (2005) The lithosphere-asthenosphere boundary in the North-West Atlantic region. Earth and Planetary Science Letters, 236, 249-257.

Le Breton, E., Cobbold, P.R. and Zanella, A. (2013) Cenozoic reactivation of the Great Glen Fault, Scotland: additional evidence and possible causes. Journal of the Geological Society, 170, 403-415.

Lloyd, F.E., Edgar, A.D., Forsyth, D.M. and Barnett, R.L. (1991) The paragenesis of upper-mantle xenoliths from the Quaternary volcanics South-East of Gees, West Eifel, Germany. Mineralogical Magazine, 55, 95-112.

Long, A.M., Menzies, M.A., Thirlwall, M.F., Upton, B.G.J. and Apsen, P. (1991) Carbonatite-mantle interaction: A possible origin for megacryst/xenolith suites in Scotland. In: Proceedings of the Fifth International Kimberlite Conference (H.O.A. Meyer and O.H. Leonardos, editors). Brazil.

McDonald, I. and Viljoen, K.S. (2006) Platinum-group element geochemistry of mantle eclogites: a reconnaissance study of xenoliths from the Orapa kimberlite, Botswana. Applied Earth Science, 115, 81-93.

McDonough, W.F. and Sun, S. (1995) The Composition of the Earth. Chemical Geology, 120, 223-253.

Menzies, M. and Halliday, A. (1988) Lithospheric mantle domains beneath the Archean and Proterozoic crust of Scotland. Journal of Petrology, Special Lithosphere Issue, 275-302.

Menzies, M.A., Halliday, A.N., Palacz, Z., Hunter, R.N., Upton, B.G.J., Aspen, P. and Hawkesworth, C.J. (1987) Evidence from mantle xenoliths for an enriched lithospheric keel under the Outer Hebrides. Nature, 325, 44-47.

Mercier, J.-C.C. and Nicolas, A. (1975) Textures and fabrics of upper-mantle peridotites as illustrated by xenoliths from basalts. Journal of Petrology, 16, 454-487.

Moorhouse, S.J. and Moorhouse, V.E. 1977. A Lewisian basement sheet within the Moine at Ribigill, north Sutherland. Scottish Journal of Geology, 13, 289-300.

Neilson, J.C., Kokelaar, B.P. and Crowley, Q.G. (2009) Timing, relations and cause of plutonic and volcanic activity of the Siluro-Devonian post-collisions magmatic episode in the Grampian Terrance, Scotland. Journal of the Geological Society, London, 166, 545-561.

Oliver, G.J.H., Wilde, S.A. and Wan, Y.S. (2008) Geochronology and geodynamics of Scottish granitoids from the late Neoproterozoic break-up of Rodinia to Palaeozoic collision. Journal of the Geological Society, London, 165, 661-674.

Park, R.G. (1994) Early Proterozoic tectonic overview of the northern British Isles and neighbouring terrains in Laurentia and Baltica. Precambrian Research, 68, 65-79.

Park, R.G. (1995) Palaeoproterozoic Laurentia-Baltica relationships: a view from the Lewisian. Pp. 211-224 in: Early Precambrian Processes (M.P. Coward and A.C. Ries, editors). Geological Society Sepcial Publications, 95. The Geological Society, London.

Park, R.G. (2005) The Lewisian terraine model: a review. Scottish Journal of Geology, 41, 105-118.

Pearce, J.A. (1996) A user's guide to basalt discrimination diagrams. Pp. 79-114 in: Trace Element Geochemistry of Volcanic Rocks: Applications for Massive Sulphide Exploration (D.A. Wyman, editor). Geological Association of Canada, Winnipeg, Germany.

Pearson, D.G., Canil, D. and Shirey, S.B. (2003) Mantle samples included in volcanic rocks: Xenoliths and diamonds. Pp. 171-275 in: Treatise on Geochemistry 2. (R.W. Carlso, H.D. Holland and K.K. Turekian, editors). Elsevier, Amsterdam.

Praegel, N.-O. (1981) Origin of ultramafic inclusions and megacrysts in a monchiquite dyke at Streap, Inverness-shire, Scotland. Lithos, 14, 305-322.

Rollinson, H.R. (1993) Using Geochemical Data: Evaluation, Presentation, Interpretation. Longman, Harlow, UK.

Sand, K.K., Waight, T.E., Pearson, D.G., Nielsen, T.F.D., Makovicky, E. and Hutchison, M.T. (2009) The lithospheric mantle below southern West Greenland: A geothermobarometric approach to diamond potential and mantle stratigraphy. Lithos, 112, 1155-1166.

Saunders, A.D., Fitton, J.G., Kerr, A.C., Norry, M.J. and Kent, R.W. (1997) The North Atlantic Igneous Province. Pp. 45-93 in: Large Igneous Provinces: Continental, Oceanic, and Planetary Flood 
Volcanism (J.J. Mahoney and M.F. Coffin, editors). American Geophysical Union, Washington D.C.

Szilas, K., van Hinsberg, V.J., Creaser, R.A. and Kisters, A.F. (2014) The geochemical composition of serpentinites in the Mesoarchaean Tartoq Group, SW Greenland: Harzburgitic cumulates or meltmodified mantle? Lithos, 198, 103-116.

Silver, P.G., Mainprice, D., Ben Ismail, A., Tommasi,, W. and Barruol, G. (1999) Mantle structural geology from seismic anisotropy. Pp. 79-103 in: Mantle petrology: Field observations and high pressure experimentation. A tribute to Francis R. (Joe) Boyd (Y. Fei, C. Bertka and B.O. Mysen, editors). Geochemical Society, Special Publications.

Stewart, M., Strachan, R.A., Martin, M.W. and Holdsworth, R.E. (2001) Constraints on early sinistral displacements along the Great Glen Fault Zone, Scotland: structural setting U-Pb geochronology and emplacement of the syn-tectonic Clunes tonalite. Journal of the Geological Society, London, 158, 821-830.

Stone, P., Floyd, J.D., Barnes, R.P. and Lintern, B.C. (1987) A sequential back-arc and foreland basin thrust duplex model for the Southern Uplands of Scotland. Journal of the Geological Society, London, 144, 753-764.

Tanner, P.W.G. (1970) The Sgurr Beag Slide - a major tectonic break within the Moinian of the Western Highlands of Scotland. Quarterly Journal of the Geological Society, 126, 435-463.

Tappe, S., Foley, S.F., Jenner, G.A., Heaman, L.M., Kjarsgaard, B.A., Romer, R.L., Stracke, A., Joyce and N. Hoefs, J. (2006) Genesis of ultramafic lamprophyres and carbonatites at Aillik Bay, Labrador: a consequence of incipient lithospheric thinning beneath the North Atlantic Craton. Journal of Petrology, 47, 1261-1315.

Tappe, S., Foley, S.F., Stracke, A., Romer, R.L., Kjarsgaard, B.A., Heaman, L.M. and Joyce, M. (2007) Craton reactivation on the Labrador Sea margins: $40 \mathrm{Ar} / 39 \mathrm{Ar}$ age and $\mathrm{Sr}-\mathrm{Nd}-\mathrm{Hf}-\mathrm{Pb}$ isotope constraints from alkaline and carbonatite intrusives. Earth and Planetary Science Letters, 256, 433-454.

Tappe, S., Smart, K.A., Pearson, D.G., Steenfelt, A. and Simonetti, A. (2011) Craton formation in Late Archean subduction zones revealed by first Greenland eclogites. Geology, 39, 1103-1106.

Till, C.B., Grove, T.L. and Withers., A.C. (2012) The beginnings of hydrous mantle wedge melting, Contributions to Mineralogy and Petrology, 163, $669-688$.

Tompkins, L.A., Bailey, S.W. and Haggerty, S.E. (1984) Kimberlitic chlorites from Sierra Leone, West Africa; unusual chemistries and structural polytypes. American Mineralogist, 69, 237-249.

Upton, B.J.G., Aspen, P. and Chapman, N.A. (1983) The upper mantle and deep crust beneath the British Isles: evidence from inclusions in volcanic rocks. Journal of the Geological Society, 140, 105-121.

Upton, B.G.J., Hinton, R.W., Aspen, P., Finch, A. and Valley, J.W. (1999) Megacrysts and Associated Xenoliths: Evidence for Migration of Geochemically Enriched Melts in the Upper Mantle beneath Scotland. Journal of Petrology, 40, 935-956.

Upton, B.G.J., Stephenson, D., Smedley, P.M., Wallis, S.M., Fitton, J.G. (2004) Carboniferous and Permian magmatism in Scotland. Pp. 195-218 in: PermoCarboniferous Magmatism and Rifting in Europe (M. Wilson, E.-R. Neumann, G.R. Davies, M.J. Timmerman, M. Heeremans and B.T. Larsen, editors). Geological Society Special Publications, 223. The Geological Society, London.

Upton, B.G.J., Finch, A.A. and Slaby, E. (2009) Megacrysts and salic xenoliths in Scottish alkali basalts: derivatives of deep crustal intrusions and small-melt fractions from the upper mantle. Mineralogical Magazine, 73(6), 895-908.

Upton, B.G.J., Downes, H., Kirstein, L.A., Bonadiman, C., Hill, P.G. and Ntaklos, T. (2011) The lithospheric mantle and lower crust-mantle relationships under Scotland: a xenolithic perspective. Journal of the Geological Society, 168, 873-886.

Vernon, R., Holdsworth, R.E., Selby, D., Dempsey, E., Finlay, A.J. and Fallick, A.E. (2014) Structural characteristics and $\mathrm{Re}-\mathrm{Os}$ dating of quartz-pyrite veins in the Lewisian Gneiss Complex, NW Scotland: Evidence of an Early Paleoproterozoic hydrothermal regime during terrane amalgamation. Precambrian Research, 246, 256-267.

Walker, G.P.L. and Ross, J.V. (1954) A xenolithic monchiquite dyke near Glenfinnan, Inverness-shire. Geological Magazine, 91, 463-472.

Wittig, N., Baker, J.A. and Downes, H. (2006) Dating the mantle roots of young continental crust. Geology, 34, 237.

Wittig, N., Pearson, D.G., Webb, M., Ottley, C.J., Irvine, G.J., Kopylova, M., Jensen, S.M. and Nowell, G.M. (2008) Origin of cratonic lithospheric mantle roots: A geochemical study of peridotites from the North Atlantic Craton, West Greenland. Earth and Planetary Science Letters, 274, 24-33.

Wittig, N., Webb, M., Pearson, D.G., Dale, C.W., Ottley, C.J., Hutchison, M., Jensen, S.M. and Luguet, A. (2010) Formation of the North Atlantic Craton: Timing and mechanisms constrained from $\mathrm{Re}-\mathrm{Os}$ isotope and PGE data of peridotite xenoliths from S.W. Greenland. Chemical Geology, 276, 166-187. Young, B.N., Parsons, I. and Threadgould, R. (1994) Carbonatite near the Loch Borralan intrusion, Assynt. Journal of the Geological Society, London, 45, 945-954. 